Pak. j. sci. ind. res. Ser. B: biol. sci. 2021 64B(2) 142-159

\title{
Phenology, Growth, Yield and Nitrogen Uptake of Wheat in Response to Nitrogen, Potassium and Their Application Methods
}

\author{
Asad Ali Khan, Inamullah Khan, Muhammad Faheem Jan*, Waqas Liaqat, \\ Asim Muhammad, Shahenshah and Shazma Anwar \\ Department of Agronomy, Faculty of Crop Production, The University of Agriculture Peshawar, Pakistan
}

(received July 2, 2018; revised April 1, 2019; accepted April 10, 2019)

\begin{abstract}
Application of macronutrients in less amount along with improper application method(s) are the major factors for low yield. Experiments were designed with the objectives to determine the optimum rate of nitrogen $(\mathrm{N})$ and potassium $(\mathrm{K})$ along with suitable application method to minimize nutrients losses. The experimental site was New Developmental Farm of the University of Agriculture Peshawar and experiments were conducted for two consecutive years i.e. 2010-11 and 2011-12. After analysis, the results indicated that both $\mathrm{N}$ and $\mathrm{K}$ significantly affected days to phenology (anthesis and maturity). Days to phenology increased linearly with increase in rate of $\mathrm{N}$ and $\mathrm{K}$ and more days to phenology were recorded when both were at their highest rates. Similarly plant height, leaf area/tiller, flag leaf area, leaf area index, leaf area duration, grain yield, $\mathrm{N}$ uptake by grains and straw were increased with increasing level of $\mathrm{N}$ and $\mathrm{K}$ and attained maximum value when $\mathrm{N}$ and $\mathrm{K}$ was applied at the rate of 180 and $90 \mathrm{Kg} / \mathrm{ha}$, respectively. Nutrients application method significantly affected plant height, leaf area/tiller, flag leaf area, grain yield and $\mathrm{N}$ uptake by straw and grains with maximum values for these traits were recorded when nutrients ( $\mathrm{N}$ and $\mathrm{K}$ ) were applied in such a combination that $15 \%$ nutrients were supplied through foliar and $85 \%$ through soil application. Application methods had a non-significant effect on days to phenology, leaf area index and leaf area duration. It is concluded from the results that application of $\mathrm{N}$ and $\mathrm{K}$ at the rate of 180 and $90 \mathrm{Kg} /$ ha respectively in such a way that $15 \%$ is applied through foliar spray and $85 \%$ through soil application improved growth, yield and $\mathrm{N}$ uptake of wheat crop under the semi-arid climate.
\end{abstract}

Keywords: Triticum aestivum L., foliar application, days to maturity, plant height, leaf area index, grain yield, $\mathrm{N}$ uptake by grains

\section{Introduction}

Wheat (Triticum aestivum L.), an important cereal crop grown all over the world to feed the masses. Pakistan is $8^{\text {th }}$ largest wheat producer and its contribution to the World's wheat production is about $3.2 \%$. In agriculture sector of Pakistan wheat is the most important staple crop and holds central position among other cereals. Fertilizers are applied to promote growth, yield, quality, shelf life and to develop resistance against insect pests and diseases in crops. Besides its use, nitrogen $(\mathrm{N})$ is still the most limited plant nutrient and wheat is very sensitive to its deficiency and very responsive to $\mathrm{N}$ fertilization (Bakht et al., 2010). It is the building block of protein and chlorophyll molecules. Therefore, amount of protein and chlorophyll formed inside the plant depend on $\mathrm{N}$ supply. Adequate application of $\mathrm{N}$ ensures quick and economic growth of the plant (Gab-Allah, 2003). Non-judicious use of $\mathrm{N}$ causes tender growth,

*Author for correspondence;

E-mail: mfaheemjan@aup.edu.pk resulting in lodging, delayed maturity and increase susceptibility to insect pests. In the list of reasons responsible for lower wheat yield, inappropriate use of fertilizers come in the top of list. Time is demanding to develop such strategies to minimize nutrients losses and provide optimum nutrients to crop for better yield and to feed masses.

Plants need huge amount of potassium $(\mathrm{K})$, because it plays an important role photosynthesis, enzyme action, protein and carbohydrates production and enables the plant to resist against diseases and pests (El-Shal, 2016). Potassium influences photosynthesis by helping Adenosine Triphosphate (ATP) formation, keeping water and carbon dioxide movement in balance through stomata as an osmo-regulator, helps in protein manufacturing by activating enzyme (nitrate reductase) and sends sugars to seeds (Wallace, 2001). K application increases $\mathrm{K}^{+}$and proline content and enhances soluble sugar in leaf. Seed size is reduced in wheat due to short supply of K and negatively affects GFD (Grain Filling 
Duration) in wheat. It has a well-built interaction with $\mathrm{N}$ and increases the uptake of $\mathrm{N}$. In Pakistan, most soils contain relatively large amount of total $\mathrm{K}$ as component of insoluble minerals. A small fraction of $\mathrm{K}$ when present as a component of insoluble mineral is available to plants (Feng et al., 2014). Potassium increases plant tolerance to drought, enhances the resistance to diseases, different pests, and keeps anion balance in plants (Wang et al., 2013). Potassium usage as a mineral fertilizer is very low in Pakistan due to socio economic status of the farmers. Most of the farmers of Pakistan are poor and hold small farms. They completely depend on chemical fertilizers and have no alternate choice except balanced use of nutrients for good yield. $\mathrm{K}$ application in Pakistan for agronomic crops is very low because farmers give less attention to its application (Adnan et al., 2016). Application of $\mathrm{K}$ has primitive effect on growth, development and grain yield in maize (Bukhsh et al., 2012) Cereal crops removed about $4 \mathrm{Kg} / \mathrm{ha}$ of $\mathrm{K}$ and about the same amount are lost due to leaching with artificial and rain water (Wallace, 2001).

Most of the fertilizers are usually applied directly to soil. In case of $\mathrm{N}$, loss of fertilizers take place through volatilization and leaching, while in case of $\mathrm{K}$, soluble portion leaches down. Foliar application of $\mathrm{N}$ and $\mathrm{K}$ may reduce their losses to some extent. Foliar application ensures rapid availability of fertilizers to plant with less chance of losses. Foliar application of $\mathrm{N}$ causes a greater increase in yield of crops (Amanullah et al., 2013). Gab-Allah et al. (2003) reported that spraying $10 \mathrm{Kg} / \mathrm{ha}$ of urea at anthesis stage increased seed protein from 10.2 to $11.8 \%$. Spraying $10 \mathrm{Kg} /$ ha urea at milk stage in wheat increased seed protein from 9.9 to $10.8 \%$ with no effect on yield (Johnson and Prince, 2002). Application method of $\mathrm{N}$ greatly affects its use efficiency and poor application method can decrease yield up to $50 \%$ (Nisar and Rashid, 2003). Soil application of $\mathrm{N}$ in combination with foliar application has been documented as an economical and effective method of $\mathrm{N}$ application (Mahajan et al., 2004). $\mathrm{N}$ when applied as a foliar improve yield, quality and is a cost-effective strategy (Siuliauskas et al., 2001). Foliar application of $\mathrm{N}$ significantly increased growth, yield and yield attributes of wheat than soil application (Wagan et al., 2017). K applied as a foliar increases leaf area duration and leaf chlorophyll content which finally results in improved yield and quality of wheat crop (Hongbo et al., 2006). The present research was designed to determine the impact of $\mathrm{N}$ and $\mathrm{K}$ (when completely applied on soil and in integration with foliar application at different percentages) on phenology, growth and quality attributes of wheat.

\section{Materials and Methods}

Experimental area description. Two field experiments were conducted at Agronomy Research Farm of the University of Agriculture Peshawar, Pakistan. The experimental site is located at $340^{\circ} 1^{\prime \prime} \mathrm{N}$ latitude and $71^{\circ} 35^{\prime \prime}$ E longitude with an altitude of $359 \mathrm{~m}$ (1178 feet) above sea level and at a distance of about 1400 $\mathrm{km}$ towards north of the Arabian sea. The environmental condition of the research farm is warm to hot having semi-arid subtropical continental climate (Khan et al., 2015). Metrological data of the experimental site during the conduction of experiment are given in Fig. 1. Soil is silt clay loam. The nature of soil is alkaline with $\mathrm{pH}$ 7.5-7.8. The soil was deficient in total $\mathrm{N}(\leq 0.5 \mathrm{~g} / \mathrm{Kg}$ of soil) and $\mathrm{K}(\leq 105 \mathrm{mg} / \mathrm{Kg})$ of soil (Asad et al., 2015). Pre-sowing soil tests were carried out for determining total $\mathrm{N}$, available phosphorus $(\mathrm{P})$ and $\mathrm{K}$, organic matter and soil $\mathrm{pH}$, results of which are given in Table 1 .

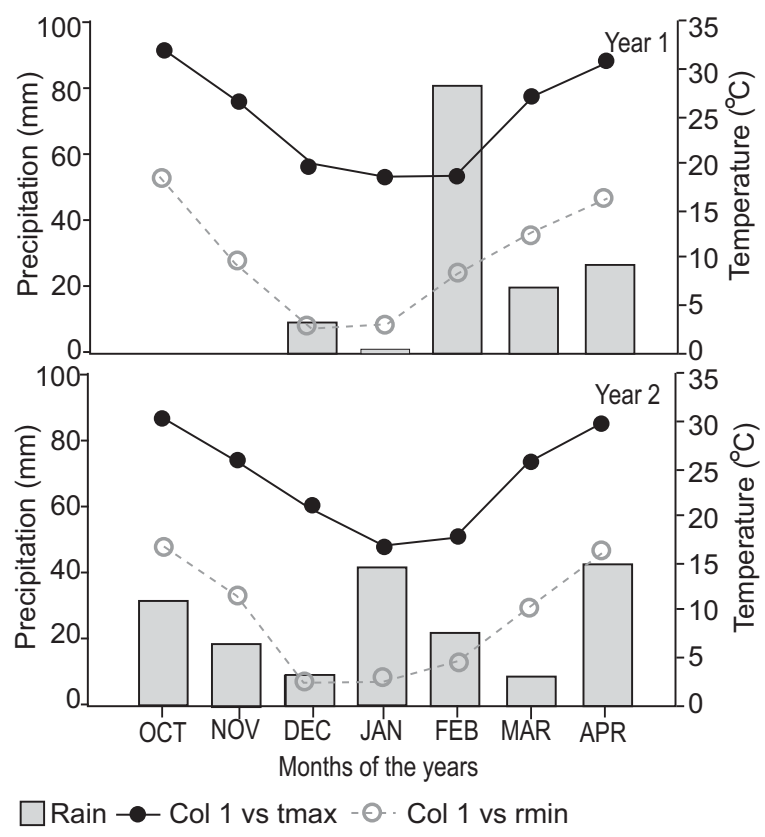

Fig. 1. Data of rainfall $(\mathrm{mm})$ are shown in bar graph while mean maximum temperature $\left({ }^{\circ} \mathrm{C}\right)$ are shown in continuous lines and minimum temperature $\left({ }^{\circ} \mathrm{C}\right)$ in dotted lines for the crop growth season (2010-12). 
Table 1. Soil physico-chemical analysis (on dry weight basis)

\begin{tabular}{lll}
\hline \hline Determination & \multicolumn{2}{c}{ Year } \\
\hline Mechanical analysis & 2010 & 2011 \\
Sand g/Kg & 180 & 180 \\
Silt g/Kg & 620 & 630 \\
Clay g/Kg & 200 & 190 \\
Soil Texture & Silty clay loam & \\
Chemical analysis & & \\
pH & 7.70 & 7.80 \\
Organic matter $(\%)$ & 0.70 & 0.84 \\
Total N $(\mathrm{g} / \mathrm{Kg})$ & 0.51 & 0.56 \\
Available P $(\mathrm{g} / \mathrm{Kg})$ & 6.82 & 6.85 \\
Available K $(\mathrm{mg} / \mathrm{Kg})$ & 89 & 105 \\
\hline \hline
\end{tabular}

Experiment detail. Experiments were designed to evaluate the impact of various nitrogen $(90,120,150$, and $180 \mathrm{Kg} / \mathrm{ha})$ and potassium $(30,60$, and $90 \mathrm{Kg} / \mathrm{ha})$ levels with different application methods (Soil application, $95 \%$ soil $+5 \%$ foliar, $90 \%$ soil $+10 \%$ foliar and $85 \%$ soil $+15 \%$ foliar) on phenology, growth and quality of wheat. Half of the soil applied $\mathrm{N}$ was incorporated at the time of sowing and the remaining half with first irrigation about three weeks after emergence. Complete dose of soil $\mathrm{K}$ was applied at the time of sowing. Foliar spray was started at tillering (Zadoks scale no.21) (Zadoks et al., 1974) and completed within two weeks. Experiments were carried out in randomized complete block design with split plot arrangement having three replications. Nutrient application methods (M) were allotted to main plots, while combinations of $\mathrm{N}$ and $\mathrm{K}$ were allotted to subplots. A subplot size of $1.8 \mathrm{~m} \times 5 \mathrm{~m}$ comprised of 6 rows 30 $\mathrm{cm}$ apart was sown using commercial wheat variety "SIRAN". Pre-sowing soil tests were carried out for determining total $\mathrm{N}$, available phosphorus $(\mathrm{P})$ and $\mathrm{K}$, organic matter and soil $\mathrm{pH}$, results of which are given in Table 1. Soil N was determined by Kjeldahl procedure (Bremmer and Mulvaney, 1982). N was applied in the form of urea and $\mathrm{K}$ in the form of MOP (murate of potash). A basal dose of phosphorous (P) was applied in the form of single super phosphate @ $90 \mathrm{Kg} / \mathrm{P}_{2} \mathrm{O}_{5}$ /ha. All other cultural practices carried out during the experiments for healthy crop growth were kept uniform for all treatments. Data were recorded for days to anthesis, days to physiological maturity, plant height, leaf area/tiller, flag leaf area, leaf area index, leaf area duration, grain yield, grain $\mathrm{N}$ uptake and straw $\mathrm{N}$ uptake.
Procedure for recording data. Data regarding days to anthesis were recorded from the date of sowing to date when $80 \%$ anthesis occurred in each subplot. Physiological maturity was recorded from the date of sowing till date when all the plants got matured in each subplot. Maturity was determined when glumes become yellow in each subplot. Ten random plants were selected in each subplot at maturity for determining mean plant height for each treatment. Plants were measured from base to the tip of spike with the help of measuring tape. Grain yield was recorded from tillers already harvested for biological yield. The harvested material was dried, threshed, carefully weighed and finally converted into $\mathrm{Kg} / \mathrm{ha}$.

Leaf area/tiller $\left(\mathrm{cm}^{2}\right)$ was calculated at the time of inflorescence emergence (Zadoks scale no.50) (Zadoks et al., 1974) when flag leaf blade was fully extended. Twenty representative plants were selected as samples. Leaf area of all the available leaves was measured by multiplying leaf length with leaf width and averaged. The area obtained was multiplied with factor. Factor was calculated using the following formula:

$$
\text { Factor }=\frac{\begin{array}{c}
\text { Average leaf area }[\text { of Ten representative } \\
\text { leaves } \left.\left(\mathrm{cm}^{2}\right)\right]
\end{array}}{\begin{array}{c}
\text { Average leaf lenth }(\mathrm{cm}) \times \text { Average leaf } \\
\text { width }(\mathrm{cm})[\text { of Ten leaves }]
\end{array}}
$$

Flag leaf area $\left(\mathrm{cm}^{2}\right)$ was calculated at the time of inflorescence emergence (Zadoks scale no.50) (Zadoks et al., 1974) when flag leaf blade was fully extended. Leaf area of twenty flag leaves were calculated and averaged.

Leaf area index was calculated as ratio of leaf area to ground area. Leaf area duration was calculated by using the following formula:

$$
\text { Leaf area duration }=\frac{\left(\mathrm{LA}_{2}+\mathrm{LA} 1_{1}\right)}{2 \times \text { number of days }}
$$

where:

$\mathrm{LAI}_{1}=$ Leaf area index at anthesis; $\mathrm{LAI}_{2}=$ Leaf area index at maturity.

Grain N uptake was calculated by Kjeldahl procedure (Bremmer and Mulvaney, 1982) using the following formula:

$$
\underset{(\mathrm{g} / \mathrm{Kg} \text { of grain })}{\text { Grain nitrogen }}=\frac{\text { Grain } N(\mathrm{~g}) \times 1000}{\text { Weight of grain sample }(\mathrm{g})}
$$


Straw $\mathrm{N}$ uptake was calculated using the following formula:

$$
\underset{(\mathrm{g} / \mathrm{Kg} \text { of straw })}{\operatorname{Straw} \text { uptake }}=\frac{\text { Straw N }(\mathrm{g}) \times 1000}{\text { Weight of straw sample }(\mathrm{g})}
$$

Statistical analysis. Statistical analysis was made using appropriate technique for randomized complete block design (split plot arrangement) according to Jakhro et al. (2000). Upon obtaining significant results from ANOVA, least significant difference (LSD) test was used for comparison of treatment means.

\section{Results and Discussion}

Days to anthesis. Impact of different levels of N, K and their application methods on days to anthesis of wheat are presented in Table 2. Mean of the two years indicated that various application methods showed no significant effect on days to anthesis of wheat, while $\mathrm{N}$ and $\mathrm{K}$ levels significantly affected days to anthesis. Increase in $\mathrm{N}$ levels substantially increased days to anthesis with more days to anthesis counted for $\mathrm{N}$ applied at the rate of $180 \mathrm{Kg} /$ ha followed by $150 \mathrm{Kg} / \mathrm{ha}$. Decreasing $\mathrm{N}$ levels decreased number of days to anthesis accordingly with less number of days to anthesis calculated for control plots. Similarly, increase in K level increased number of days to anthesis. More days to anthesis was calculated for $90 \mathrm{Kg}, \mathrm{K} /$ ha followed by $60 \mathrm{Kg}, \mathrm{K} / \mathrm{ha}$. Control vs rest contrast was found significant for days to anthesis with fewer days to anthesis in control than rest.

Days to physiological maturity. Effect of different levels of $\mathrm{N}, \mathrm{K}$ and their application methods on days to physiological maturity of wheat is shown in

Table 2. Days to anthesis and physiological maturity of wheat crop as influenced by nitrogen, potassium and their application methods

\begin{tabular}{|c|c|c|c|c|c|c|}
\hline \multirow[t]{2}{*}{ Treatments $(\mathrm{T})$} & \multicolumn{2}{|c|}{$\begin{array}{l}\text { Days to anthesis } \\
\text { Years }(\mathrm{Y})\end{array}$} & \multirow[b]{2}{*}{ Mean } & \multicolumn{3}{|c|}{$\begin{array}{c}\text { Days to physiological maturity } \\
\text { Years }(\mathrm{Y})\end{array}$} \\
\hline & $2010-11$ & $2011-12$ & & $2010-11$ & $2011-12$ & Mean \\
\hline \multicolumn{7}{|l|}{ Methods (M) } \\
\hline M1: All N and K soil applied & 129 & 128 & 128 & 167 & 167 & 167 \\
\hline M2: $5 \%$ foliar $+95 \%$ soil applied & 129 & 128 & 128 & 167 & 166 & 167 \\
\hline M3: $10 \%$ foliar $+90 \%$ soil applied & 129 & 128 & 128 & 167 & 166 & 167 \\
\hline M4: $15 \%$ foliar $+85 \%$ soil applied & 129 & 128 & 128 & 167 & 166 & 167 \\
\hline $\mathrm{LSD}_{0.05}$ & & & ns & & & ns \\
\hline \multicolumn{7}{|l|}{ Nitrogen (Kg/ha) } \\
\hline 90 & 126 & 125 & $126 \mathrm{~d}$ & 165 & 164 & $165 \mathrm{~d}$ \\
\hline 120 & 129 & 128 & $128 \mathrm{c}$ & 168 & 167 & $167 \mathrm{c}$ \\
\hline 150 & 131 & 130 & $130 \mathrm{~b}$ & 169 & 169 & $169 \mathrm{~b}$ \\
\hline 180 & 132 & 131 & $132 \mathrm{a}$ & 171 & 170 & $171 \mathrm{a}$ \\
\hline $\mathrm{LSD}_{0.05}$ & & & 0.2 & & & 0.2 \\
\hline \multicolumn{7}{|l|}{ Potassium (Kg/ha) } \\
\hline 30 & 129 & 128 & $128 \mathrm{c}$ & 167 & 166 & $167 \mathrm{c}$ \\
\hline 60 & 129 & 129 & $129 \mathrm{~b}$ & 168 & 168 & $168 \mathrm{~b}$ \\
\hline 90 & 130 & 129 & $130 \mathrm{a}$ & 169 & 168 & $169 \mathrm{a}$ \\
\hline $\mathrm{LSD}_{0.05}$ & & & 0.2 & & & 0.2 \\
\hline Control & 122 & 122 & $122 b$ & 155 & 155 & $155 \mathrm{~b}$ \\
\hline Rest & 128 & 129 & $129 \mathrm{a}$ & 168 & 167 & $168 \mathrm{a}$ \\
\hline Interactions & P value & & & Interactions & P value & \\
\hline \multirow[t]{3}{*}{$\mathrm{N} \times \mathrm{K}$} & 0.02 & & & $\mathrm{~N} \times \mathrm{K}$ & 0.000 & \\
\hline & & & & $\mathrm{M} \times \mathrm{N}$ & 0.000 & \\
\hline & & & & $\mathrm{M} \times \mathrm{K}$ & 0.007 & \\
\hline
\end{tabular}

Means sharing same letter(s) for a parameter in a column are statistically similar at 5\% level of significance; $n s=$ non-significant. 
Table 2. Analysis showed that various application methods had no profound impact on days to physiological maturity of wheat. However, $\mathrm{N}$ and $\mathrm{K}$ had significant impact on spikes $/ \mathrm{m}^{2}$. Increase in $\mathrm{N}$ level substantially increased number of days to physiological maturity. By taking average of two years, means showed that maximum days to physiological maturity were recorded for highest $(180 \mathrm{Kg} / \mathrm{ha})$ level of $\mathrm{N}$ followed by $150 \mathrm{Kg} / \mathrm{ha}$. Days to physiological maturity decreased significantly as level of $\mathrm{N}$ decreased. Similarly, increase in $\mathrm{K}$ level also increased number of days to physiological maturity. Averaged across two years, data revealed that significantly more number of days to physiological maturity was recorded for $90 \mathrm{Kg}, \mathrm{K} /$ ha followed by 60 $\mathrm{Kg} / \mathrm{ha}$ and $\mathrm{K}$ application against less number of days to physiological maturity recorded for $30 \mathrm{Kg}, \mathrm{K} / \mathrm{ha}$. Control vs rest was found significant for spikes $/ \mathrm{m}^{2}$.
Plant height. Data regarding plant height of wheat as affected by different $\mathrm{N}, \mathrm{K}$ levels and application methods are given in Table 3. Analysis showed that plant height of wheat was significantly affected by various N, K levels and their application methods. Interaction of treatments was found non-significant. Based on average of two years, application of $\mathrm{N}$ and $\mathrm{K}$ in such a way that $10 \%$ of $\mathrm{N}$ and $\mathrm{K}$ were applied through foliar and remaining $90 \%$ applied directly to soil resulted in tallest plant height followed by rest of the application methods with no statistical differences. Means of the two years showed that increase in $\mathrm{N}$ levels significantly increased plant height with maximum plant height recorded for $\mathrm{N}$ applied at the rate of $180 \mathrm{Kg} / \mathrm{ha}$ followed by 150 $\mathrm{Kg} / \mathrm{ha}$. Decreasing $\mathrm{N}$ rate decreased plant height of wheat crop. Similarly, increase in K increased plant height when data were averaged across two years.

Table 3. Plant height $(\mathrm{cm})$ and leaf area/tiller of wheat crop as affected by different nitrogen and potassium levels as well as their application methods

\begin{tabular}{|c|c|c|c|c|c|c|}
\hline \multirow[t]{2}{*}{ Treatments $(\mathrm{T})$} & \multicolumn{2}{|c|}{$\begin{array}{c}\text { Plant height }(\mathrm{cm}) \\
\text { Years }(\mathrm{Y})\end{array}$} & \multicolumn{4}{|c|}{$\begin{array}{c}\text { Leaf area/tiller }\left(\mathrm{cm}^{2}\right) \\
\text { Years }(\mathrm{Y})\end{array}$} \\
\hline & $2010-11$ & $2011-12$ & Mean & $2010-11$ & $2011-12$ & Mean \\
\hline \multicolumn{7}{|l|}{ Methods (M) } \\
\hline M1: All N and K soil applied & 96 & 95 & $95 \mathrm{~b}$ & 120.3 & 102.6 & $111.4 \mathrm{~d}$ \\
\hline M2: $5 \%$ foliar $+95 \%$ soil applied & 95 & 94 & $95 \mathrm{~b}$ & 123.5 & 109.2 & $116.3 \mathrm{c}$ \\
\hline M3: $10 \%$ foliar $+90 \%$ soil applied & 96 & 96 & $96 \mathrm{a}$ & 127.6 & 118.2 & $122.9 \mathrm{~b}$ \\
\hline M4: $15 \%$ foliar $+85 \%$ soil applied & 96 & 94 & $95 \mathrm{~b}$ & 132.7 & 128.1 & $130.4 \mathrm{a}$ \\
\hline $\mathrm{LSD}_{0.05}$ & & & 0.8 & & & 1.4 \\
\hline \multicolumn{7}{|l|}{ Nitrogen (Kg/ha) } \\
\hline 90 & 92 & 92 & $92 \mathrm{~d}$ & 108.1 & 100.1 & $104.1 \mathrm{~d}$ \\
\hline 120 & 97 & 96 & $96 \mathrm{c}$ & 124.3 & 111.4 & $117.9 \mathrm{c}$ \\
\hline 150 & 98 & 98 & $98 \mathrm{~b}$ & 137.5 & 123.6 & $130.5 \mathrm{~b}$ \\
\hline 180 & 101 & 99 & $100 \mathrm{a}$ & 146.6 & 134.4 & $140.5 \mathrm{a}$ \\
\hline $\mathrm{LSD}_{0.05}$ & & & 0.8 & & & 0.8 \\
\hline \multicolumn{7}{|l|}{ Potassium (Kg/ha) } \\
\hline 30 & 97 & 96 & $96 \mathrm{~b}$ & 125.7 & 113 & $119.2 \mathrm{c}$ \\
\hline 60 & 97 & 96 & $96 \mathrm{~b}$ & 129.9 & 118.1 & $124.0 \mathrm{~b}$ \\
\hline 90 & 98 & 97 & $97 \mathrm{a}$ & 132.1 & 121.1 & $126.6 \mathrm{a}$ \\
\hline $\mathrm{LSD}_{0.05}$ & & & 0.4 & & & 0.7 \\
\hline Control & 80 & 79 & $80 \mathrm{~b}$ & 88.6 & 80.3 & $84.4 \mathrm{~b}$ \\
\hline Rest & 97 & 96 & $97 \mathrm{a}$ & 129.1 & 117.4 & $123.3 \mathrm{a}$ \\
\hline Interactions & & & P value & Interactions & P value & \\
\hline $\mathrm{N} \times \mathrm{K}$ & & & 0.044 & $\mathrm{~N} \times \mathrm{K}$ & 0.002 & \\
\hline $\mathrm{M} \times \mathrm{N}$ & & & 0.000 & $\mathrm{M} \times \mathrm{N}$ & 0.000 & \\
\hline
\end{tabular}

Means sharing same letter(s) for a parameter in a column are statistically similar at $5 \%$ level of significance; ns = non-significant. 
Highest plant height was recorded for $90 \mathrm{Kg} / \mathrm{ha} \mathrm{K}$ application, while minimum plant height was recorded for control plots.

Leaf area/tiller. Data regarding leaf area/tiller of wheat as affected by various $\mathrm{N}, \mathrm{K}$ levels and their application methods are presented in Table 3. Different N, K levels and application methods significantly affected leaf area/tiller of wheat. Based on two years average, minimum leaf area/tiller was documented by the method, where all nutrients were soil applied. Maximum leaf area/tiller was recorded when $15 \%$ of the nutrients were applied as foliar and $85 \%$ as soil followed by the ratio of 10:90 (foliar: soil). When averaged across two years, significantly maximum leaf area/tiller was recorded for highest $(180 \mathrm{Kg} / \mathrm{ha})$ level of $\mathrm{N}$ followed by $150 \mathrm{Kg} / \mathrm{ha}$ and further decrease in $\mathrm{N}$ levels decreased leaf area/tiller also. A profound effect of $\mathrm{K}$ was also observed on leaf area/tiller of wheat when means were averaged for both years. Increase in $\mathrm{K}$ level from control to $90 \mathrm{Kg} / \mathrm{ha}$ increased leaf area/tiller.

Flag leaf area/tiller. Data regarding flag leaf area/tiller of wheat as affected by various N, K levels and application methods (M) are given in Table 4. Various levels of $\mathrm{N}$ and $\mathrm{K}$ as well as application methods of these nutrients significantly affected flag leaf area/tiller. Flag leaf area/tiller increased substantially with increase in $\mathrm{N}$ levels. Average of two years indicated that lowest flag leaf area/tiller was obtained with $90 \mathrm{Kg}$, N/ha which increased with increase in $\mathrm{N}$ levels and gave maximum value for $180 \mathrm{Kg}$, N/ha. Flag leaf area/tiller showed profound increase with increase in K levels. Means across two years showed that increasing $\mathrm{K}$ level increased flag leaf area/tiller with maximum yield recorded for $90 \mathrm{Kg} / \mathrm{ha} \mathrm{K}$ application. Mean across two

Table 4. Flag leaf area/tiller and leaf area index of wheat crop as influenced by nitrogen, potassium and their application methods

\begin{tabular}{|c|c|c|c|c|c|c|}
\hline \multirow[t]{2}{*}{ Treatments $(\mathrm{T})$} & \multicolumn{2}{|c|}{$\begin{array}{c}\text { Flag leaf area/tiller }\left(\mathrm{cm}^{2}\right) \\
\text { Years }(\mathrm{Y})\end{array}$} & \multirow[b]{2}{*}{ Mean } & \multicolumn{2}{|c|}{$\begin{array}{l}\text { Leaf area index } \\
\text { Years }(Y)\end{array}$} & \multirow[b]{2}{*}{ Mean } \\
\hline & $2010-11$ & $2011-12$ & & $2010-11$ & $2011-12$ & \\
\hline \multicolumn{7}{|l|}{ Methods (M) } \\
\hline M1: All N and K soil applied & 20.6 & 18.9 & $19.7 \mathrm{c}$ & 2.9 & 2.4 & 2.6 \\
\hline M2: $5 \%$ foliar $+95 \%$ soil applied & 21.5 & 19.4 & $20.5 \mathrm{~b}$ & 2.7 & 2.4 & 2.5 \\
\hline M3: $10 \%$ foliar $+90 \%$ soil applied & 22.4 & 19.8 & $21.1 \mathrm{a}$ & 2.8 & 2.4 & 2.6 \\
\hline M4: $15 \%$ foliar $+85 \%$ soil applied & 22.5 & 19.9 & $21.1 \mathrm{a}$ & 2.7 & 2.5 & 2.6 \\
\hline $\mathrm{LSD}_{0.05}$ & & & 0.1 & & & ns \\
\hline \multicolumn{7}{|l|}{ Nitrogen (Kg/ha) } \\
\hline 90 & 18.1 & 16.2 & $17.2 \mathrm{~d}$ & 2.1 & 2 & $2.1 \mathrm{~d}$ \\
\hline 120 & 20.9 & 18.7 & $19.8 \mathrm{c}$ & 2.6 & 2.3 & $2.5 \mathrm{c}$ \\
\hline 150 & 23.7 & 21.2 & $22.5 \mathrm{~b}$ & 3.1 & 2.7 & $2.9 \mathrm{~b}$ \\
\hline 180 & 26.6 & 23.7 & $25.1 \mathrm{a}$ & 3.7 & 3 & $3.3 \mathrm{a}$ \\
\hline $\mathrm{LSD}_{0.05}$ & & & 0.1 & & & 0.1 \\
\hline \multicolumn{7}{|l|}{ Potassium (Kg/ha) } \\
\hline 30 & 21.3 & 19.1 & $20.2 \mathrm{c}$ & 2.7 & 2.4 & $2.5 \mathrm{~b}$ \\
\hline 60 & 22.4 & 20 & $21.2 \mathrm{~b}$ & 2.9 & 2.5 & $2.7 \mathrm{a}$ \\
\hline 90 & 23.2 & 20.8 & $22.0 \mathrm{a}$ & 3.1 & 2.6 & $2.8 \mathrm{a}$ \\
\hline $\mathrm{LSD}_{0.05}$ & & & 0.1 & & & 0.1 \\
\hline Control & 15.1 & 14 & $14.6 \mathrm{~b}$ & 1.5 & 1.7 & $1.6 \mathrm{~b}$ \\
\hline Rest & 22.3 & 19.9 & $21.1 \mathrm{a}$ & 2.9 & 2.5 & $2.7 \mathrm{a}$ \\
\hline Interactions & P value & & & Interactions & P value & \\
\hline $\mathrm{N} \times \mathrm{K}$ & 0.045 & & & $\mathrm{M} \times \mathrm{N}$ & 0.042 & \\
\hline $\mathrm{M} \times \mathrm{N}$ & 0.000 & & & & & \\
\hline $\mathrm{M} \times \mathrm{K}$ & 0.000 & & & & & \\
\hline
\end{tabular}

Means sharing same letter(s) for a parameter in a column are statistically similar at 5\% level of significance; $n s=$ non-significant. 
years showed that highest flag leaf area/tiller was obtained when nutrients ( $\mathrm{N}$ and $\mathrm{K}$ ) were applied at ratio of 15: 85 (foliar: soil) which was statistically similar with the ratio of 10: 90 (foliar: soil), while lowest flag leaf area/tiller was recorded in plots where all nutrients were applied directly to the soil.

Leaf area index. Impact of different levels of N, K and their application methods on leaf area index of wheat are presented in Table 4. Mean of the two years indicated that various application methods showed no significant effect on leaf area index of wheat. While $\mathrm{N}$ and $\mathrm{K}$ levels significantly affected leaf area index. Increase in $\mathrm{N}$ levels substantially increased leaf area index with maximum leaf area index recorded for $\mathrm{N}$ applied at the rate of $180 \mathrm{Kg} / \mathrm{ha}$ followed by $150 \mathrm{Kg} / \mathrm{ha}$. Decreasing $\mathrm{N}$ levels decreased leaf area index accordingly with minimum leaf area index calculated for control plots. Similarly, increase in $\mathrm{K}$ level increased leaf area index. Highest leaf area index was calculated for $90 \mathrm{Kg}, \mathrm{K} / \mathrm{ha}$ followed by $60 \mathrm{Kg}$, K/ha with no statistical difference. Control vs rest contrast was found significant for leaf area index with lowest leaf area index recorded in control than rest.

Leaf area duration. Effect of different levels of N, K and their application methods on leaf area duration of wheat is shown in Table 5. Analysis showed that various application methods had no profound impact on leaf area duration of wheat. However, $\mathrm{N}$ and $\mathrm{K}$ had significant impact on leaf area duration. Increase in $\mathrm{N}$ level substantially increased leaf area duration. By taking average of two years, means showed that maximum leaf area duration was recorded for highest $(180 \mathrm{Kg} / \mathrm{ha})$ level of $\mathrm{N}$ followed by $150 \mathrm{Kg} / \mathrm{ha}$. Leaf area duration decreased significantly as level of N decreased. Similarly, increase in $\mathrm{K}$ level also increased leaf area duration. Averaged across two years, data revealed that significantly more leaf area duration was recorded for $90 \mathrm{Kg}, \mathrm{K} /$ ha which was followed by $60 \mathrm{Kg} / \mathrm{ha}$ and $\mathrm{K}$ application against

Table 5. Leaf area duration and grain yield $(\mathrm{Kg} / \mathrm{ha})$ of wheat as affected by nitrogen, potassium and their application methods

\begin{tabular}{|c|c|c|c|c|c|c|}
\hline \multirow[t]{2}{*}{ Treatments $(\mathrm{T})$} & \multicolumn{2}{|c|}{$\begin{array}{c}\text { Leaf area duration } \\
\text { Years }(\mathrm{Y})\end{array}$} & \multicolumn{4}{|c|}{$\begin{array}{c}\text { Grain yield }(\mathrm{Kg} / \mathrm{ha}) \\
\text { Years }(\mathrm{Y})\end{array}$} \\
\hline & $2010-11$ & $2011-12$ & Mean & $2010-11$ & $2011-12$ & Mean \\
\hline \multicolumn{7}{|l|}{ Methods (M) } \\
\hline M1: All N and K soil applied & 104 & 87 & 95 & 3947.7 & 3768.9 & $3858.3 \mathrm{c}$ \\
\hline M2: $5 \%$ foliar $+95 \%$ soil applied & 98 & 87 & 93 & 4082.9 & 3869.4 & $3976.2 \mathrm{ab}$ \\
\hline M3: $10 \%$ foliar $+90 \%$ soil applied & 100 & 87 & 94 & 4219.3 & 4064.7 & $4142.0 \mathrm{a}$ \\
\hline M4: $15 \%$ foliar $+85 \%$ soil applied & 100 & 89 & 94 & 4253.6 & 4094.6 & $4174.1 \mathrm{a}$ \\
\hline $\mathrm{LSD}_{0.05}$ & & & ns & & & 71.4 \\
\hline \multicolumn{7}{|l|}{ Nitrogen (Kg/ha) } \\
\hline 90 & 76 & 68 & $72 \mathrm{~d}$ & 3969.8 & 3797.6 & $3883.7 \mathrm{~d}$ \\
\hline 120 & 94 & 85 & $90 \mathrm{c}$ & 4274.7 & 3962.0 & $4118.4 \mathrm{c}$ \\
\hline 150 & 114 & 99 & $107 \mathrm{~b}$ & 4385.9 & 4200.6 & $4293.3 b$ \\
\hline 180 & 136 & 111 & $123 \mathrm{a}$ & 4424.2 & 4362.2 & $4393.2 \mathrm{a}$ \\
\hline $\mathrm{LSD}_{0.05}$ & & & 2.4 & & & 47.5 \\
\hline \multicolumn{7}{|l|}{ Potassium (Kg/ha) } \\
\hline 30 & 97 & 86 & $92 \mathrm{c}$ & 4101.9 & 3942.1 & $4022.0 \mathrm{c}$ \\
\hline 60 & 105 & 91 & $98 \mathrm{~b}$ & 4311.0 & 4082.9 & 4197.0b \\
\hline 90 & 112 & 95 & $104 \mathrm{a}$ & 4378.1 & 4216.8 & $4297.4 \mathrm{a}$ \\
\hline $\mathrm{LSD}_{0.05}$ & & & 2.1 & & & 41.1 \\
\hline Control & 48 & 49 & $48 b$ & 2472.6 & 2374.9 & $2423.8 b$ \\
\hline Rest & 105 & 91 & $98 \mathrm{a}$ & 4263.7 & 4080.6 & $4172.1 \mathrm{a}$ \\
\hline \multirow[t]{2}{*}{ Interactions } & \multirow{2}{*}{\multicolumn{3}{|c|}{ P value }} & \multicolumn{3}{|c|}{ Interactions P value } \\
\hline & & & & $\mathrm{M} \times \mathrm{N}$ & 0.000 & \\
\hline
\end{tabular}

Means sharing same letter(s) for a parameter in a column are statistically similar at 5\% level of significance; $n s=$ non-significant. 
minimum leaf area duration recorded for $30 \mathrm{Kg}, \mathrm{K} / \mathrm{ha}$. Control vs rest was found significant for leaf area duration.

Grain yield (Kg/ha). Data regarding grain yield of wheat as affected by various $\mathrm{N}, \mathrm{K}$ levels and $\mathrm{M}$ are given in Table 5. Various levels of $\mathrm{N}$ and $\mathrm{K}$ as well as $\mathrm{M}$ of these nutrients significantly affected grain yield. Grain yield increased substantially with increase in $\mathrm{N}$ levels. Average of two years indicated that lowest grain yield was obtained with $90 \mathrm{Kg}$, N/ha which increased with increase in $\mathrm{N}$ levels and gave maximum value for $180 \mathrm{Kg}, \mathrm{N} / \mathrm{ha}$. Grain yield showed profound increase with increase in K levels. Means across two years showed that increasing $\mathrm{K}$ level increased grain yield with maximum yield recorded for $90 \mathrm{Kg} / \mathrm{ha} \mathrm{K}$ application. Mean across two years showed that highest grain yield was obtained when nutrients ( $\mathrm{N}$ and $\mathrm{K}$ ) were applied at ratio of 15: 85 (foliar: soil) which was statistically similar with rest of the ratios while lowest grain yield was recorded in plots where all nutrients were applied directly to the soil.

$\mathrm{N}$ uptake by grains (g/Kg). Data regarding $\mathrm{N}$ uptake by grains of wheat as affected by different $\mathrm{N}, \mathrm{K}$ levels and $\mathrm{M}$ are given in Table 6 . Analysis showed that $\mathrm{N}$ uptake by grains of wheat was significantly affected by various N, K levels and their application methods. Based on average of two years, data revealed that application of $\mathrm{N}$ and $\mathrm{K}$ in such a way that $15 \%$ of $\mathrm{N}$ and $\mathrm{K}$ was applied through foliar and remaining 85\% applied directly to soil resulted in maximum $\mathrm{N}$ uptake by grains followed by treatment of $10 \%$ foliar $+90 \%$ soil applied $\mathrm{N}$ and $\mathrm{K}$. Minimum $\mathrm{N}$ uptake by grains was recorded when all of $\mathrm{N}$ and $\mathrm{K}$ was applied directly to the soil. Means of the two years showed that increase in $\mathrm{N}$ levels

Table 6. Nitrogen uptake by grain $(\mathrm{g} / \mathrm{Kg})$ and $\mathrm{N}$ uptake by straw $(\mathrm{g} / \mathrm{Kg})$ of wheat crop as influenced by nitrogen, potassium and their application methods

\begin{tabular}{|c|c|c|c|c|c|c|}
\hline \multirow[t]{2}{*}{ Treatments $(\mathrm{T})$} & \multicolumn{3}{|c|}{$\begin{array}{c}\text { N uptake by grain }(\mathrm{g} / \mathrm{Kg}) \\
\text { Years }(\mathrm{Y})\end{array}$} & \multicolumn{3}{|c|}{$\begin{array}{c}\text { N uptake by straw }(\mathrm{g} / \mathrm{Kg}) \\
\text { Years }(\mathrm{Y})\end{array}$} \\
\hline & $2010-11$ & $2011-12$ & Mean & $2010-11$ & $2011-12$ & Mean \\
\hline \multicolumn{7}{|l|}{ Methods (M) } \\
\hline M1: All N and K soil applied & 7.3 & 6.31 & $6.80 \mathrm{~d}$ & 1.23 & 1.25 & $1.24 \mathrm{~b}$ \\
\hline M2: $5 \%$ foliar $+95 \%$ soil applied & 7.77 & 6.56 & $7.17 \mathrm{c}$ & 1.31 & 1.36 & $1.33 b$ \\
\hline M3: $10 \%$ foliar $+90 \%$ soil applied & 8.14 & 7.53 & $7.84 b$ & 1.37 & 1.23 & $1.30 \mathrm{~b}$ \\
\hline M4: $15 \%$ foliar $+85 \%$ soil applied & 8.51 & 7.92 & $8.21 \mathrm{a}$ & 1.69 & 1.49 & $1.59 \mathrm{a}$ \\
\hline $\mathrm{LSD}_{0.05}$ & & & 0.31 & & & 0.18 \\
\hline \multicolumn{7}{|l|}{ Nitrogen (Kg/ha) } \\
\hline 90 & 6.4 & 5.27 & $5.83 \mathrm{~d}$ & 0.91 & 0.96 & $0.94 \mathrm{~d}$ \\
\hline 120 & 7.84 & 6.73 & $7.28 \mathrm{c}$ & 1.25 & 1.16 & $1.20 \mathrm{c}$ \\
\hline 50 & 8.96 & 8.23 & $8.59 b$ & 1.67 & 1.48 & $1.57 \mathrm{~b}$ \\
\hline 80 & 10.24 & 9.73 & $9.98 \mathrm{a}$ & 1.96 & 1.93 & $1.95 \mathrm{a}$ \\
\hline $\mathrm{LSD}_{0.05}$ & & & 0.18 & & & 0.05 \\
\hline \multicolumn{7}{|l|}{ Potassium (Kg/ha) } \\
\hline 30 & 7.68 & 6.72 & $7.20 \mathrm{c}$ & 1.28 & 1.26 & $1.27 \mathrm{c}$ \\
\hline 60 & 8.42 & 7.48 & $7.95 \mathrm{~b}$ & 1.48 & 1.35 & $1.41 \mathrm{~b}$ \\
\hline 90 & 8.97 & 8.27 & $8.62 \mathrm{a}$ & 1.58 & 1.54 & $1.56 \mathrm{a}$ \\
\hline $\mathrm{LSD}_{0.05}$ & & & 0.16 & & & 0.04 \\
\hline Control & 2.79 & 2.19 & $2.49 \mathrm{~b}$ & 0.81 & 0.72 & $0.77 \mathrm{~b}$ \\
\hline Rest & 8.36 & 7.49 & $7.92 \mathrm{a}$ & 1.45 & 1.38 & $1.42 \mathrm{a}$ \\
\hline Interactions & P value & & & Interact & $P$ value & \\
\hline $\mathrm{N} \times \mathrm{K}$ & 0.000 & & & $\mathrm{~N} \times \mathrm{K}$ & 0.000 & \\
\hline $\mathrm{M} \times \mathrm{N}$ & 0.000 & & & $\mathrm{M} \times \mathrm{N}$ & 0.000 & \\
\hline $\mathrm{M} \times \mathrm{K}$ & 0.011 & & & & & \\
\hline
\end{tabular}

Means sharing same letter(s) for a parameter in a column are statistically similar at $5 \%$ level of significance; ns = non-significant. 
significantly increased $\mathrm{N}$ uptake by grains with maximum $\mathrm{N}$ uptake by grains recorded for $\mathrm{N}$ applied at the rate of $180 \mathrm{Kg}$ /ha followed by $150 \mathrm{Kg}, \mathrm{N} / \mathrm{ha}$ application. Similarly, increase in $\mathrm{K}$ rate increased $\mathrm{N}$ uptake by grains when data were averaged across two years. Highest $\mathrm{N}$ uptake by grains was recorded for $90 \mathrm{Kg} / \mathrm{ha}$ $\mathrm{K}$ application while minimum $\mathrm{N}$ uptake by grains was recorded for control plots.

$\mathbf{N}$ uptake by straw (g/Kg). Data in Table 6 exhibits $\mathrm{N}$ uptake by straw in wheat as affected by various $\mathrm{N}, \mathrm{K}$ levels and application methods. Based on average of two years, data indicated that $\mathrm{N}$ uptake by straw increased significantly with increase in $\mathrm{N}$ levels and showed a positive relation with $\mathrm{N}$ levels. Maximum N uptake by straw was recorded with the application of $180 \mathrm{Kg}$, N/ha followed by $120 \mathrm{Kg}$, N/ha. Lesser value for $\mathrm{N}$ uptake by straw was recorded for $90 \mathrm{Kg} / \mathrm{ha} \mathrm{N}$ application. Based on average of two years, data showed that $\mathrm{N}$ uptake by straw increased substantially with increase in $\mathrm{K}$ levels and reached to maximum value for $\mathrm{K}$ applied at the rate of $90 \mathrm{Kg} / \mathrm{ha}$ against minimum value recorded for $30 \mathrm{Kg} / \mathrm{ha}$. Averaged across two years, maximum $\mathrm{N}$ uptake by straw was recorded for nutrients applied at the ratio of 15:85 as foliar and soil followed by ratio of 10:90 which was statistically similar with rest of the ratios.

Interactions. Interaction between $N$ and $K$ for days to anthesis and physiological maturity of wheat. Interaction of $\mathrm{N} \times \mathrm{K}$ for days to anthesis of wheat (Fig. 2) indicated that increasing $\mathrm{N}$ level significantly increased days to anthesis for all levels of $\mathrm{K}$ and vice versa. Maximum days to anthesis were recorded when $\mathrm{N}$ was applied at the rate of $180 \mathrm{Kg} / \mathrm{ha}$ and $\mathrm{K}$ at the rate of $90 \mathrm{Kg} / \mathrm{ha}$, while minimum days to anthesis were recorded when both $\mathrm{N}$ and $\mathrm{K}$ were applied at their lowest rate, i.e. 90 and $30 \mathrm{Kg} / \mathrm{ha}$, respectively.

Interaction of $\mathrm{N} \times \mathrm{K}$ (Fig. 3) indicated that days to maturity increased significantly when both $\mathrm{N}$ and $\mathrm{K}$ increased simultaneously with maximum days to maturity recorded when both $\mathrm{N}$ and $\mathrm{K}$ were at their highest rate i.e. 180 and $90 \mathrm{Kg} / \mathrm{ha}$. Minimum days to maturity were recorded when $\mathrm{N}$ and $\mathrm{K}$ were at their lowest rate.

Interaction between methods and $N$ and $K$ for days to physiological maturity of wheat. This interaction revealed that increasing $\mathrm{N}$ rate increased days to maturity for all levels of application methods of nutrients (Fig. 4). Maximum days to maturity were recorded

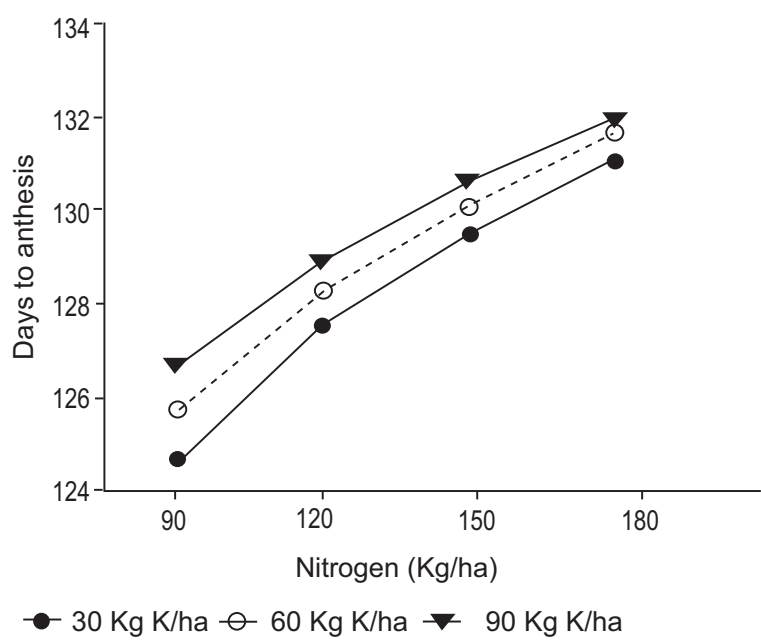

Fig. 2. Interaction of $\mathrm{N} \times \mathrm{K}$ for days to anthesis.

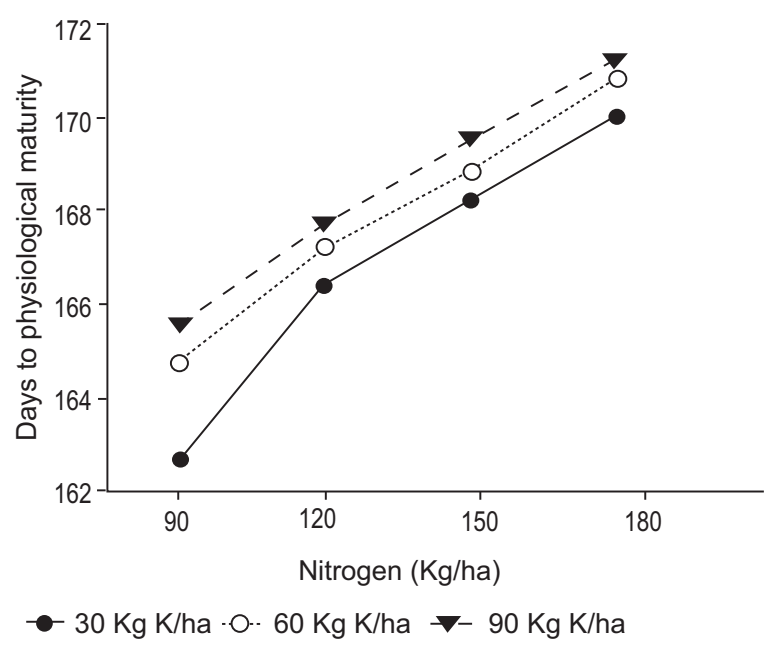

Fig. 3. $\mathrm{N} \times \mathrm{K}$ interaction for physiological maturity.

when $180 \mathrm{Kg}, \mathrm{N} / \mathrm{ha}$ was applied in such a way that $15 \%$ $\mathrm{N}$ was applied through foliar and $85 \%$ directly to soil. Minimum days to maturity were recorded when 90 $\mathrm{Kg} / \mathrm{ha}$ of $\mathrm{N}$ was applied in the ratio of 5: 95 as foliar: soil.

Methods and $\mathrm{K}$ interaction indicated (Fig. 5) that application of $30 \mathrm{Kg}, \mathrm{K} / \mathrm{ha}$ in such a way that $5 \% \mathrm{~K}$ was supplied through foliar and remaining 95\% through soil resulted in less days to physiological maturity while the same ratio of foliar to soil application of $\mathrm{K}$ resulted in more days to maturity when $\mathrm{K}$ was increased to 90 $\mathrm{Kg} / \mathrm{ha}$.

$\mathrm{N}$ and $\mathrm{K}$ interaction for plant height of wheat. $\mathrm{N} \times$ $\mathrm{K}$ interaction (Fig. 6) showed that with increase in $\mathrm{N}$ 
rate plant height increased substantially for all levels of K. Taller plants were recorded when $\mathrm{N}$ and $\mathrm{K}$ was applied at the rate of 180 and $90 \mathrm{Kg} / \mathrm{ha}$, respectively. Short statured plants were recorded when both $\mathrm{N}$ and $\mathrm{K}$ was applied at their lowest rate.

Plant height of wheat in response to methods and $\mathbf{N}$ interaction. Plant height substantially increased with increase in $\mathrm{N}$ rate with minimum plant height recorded when $90 \mathrm{Kg}$, N/ha was completely applied to soil (Fig. 7). At $90 \mathrm{Kg}$, N/ha maximum plant height was recorded when it was applied in the ratio of 15:85 (foliar: soil) while maximum plant height was recorded

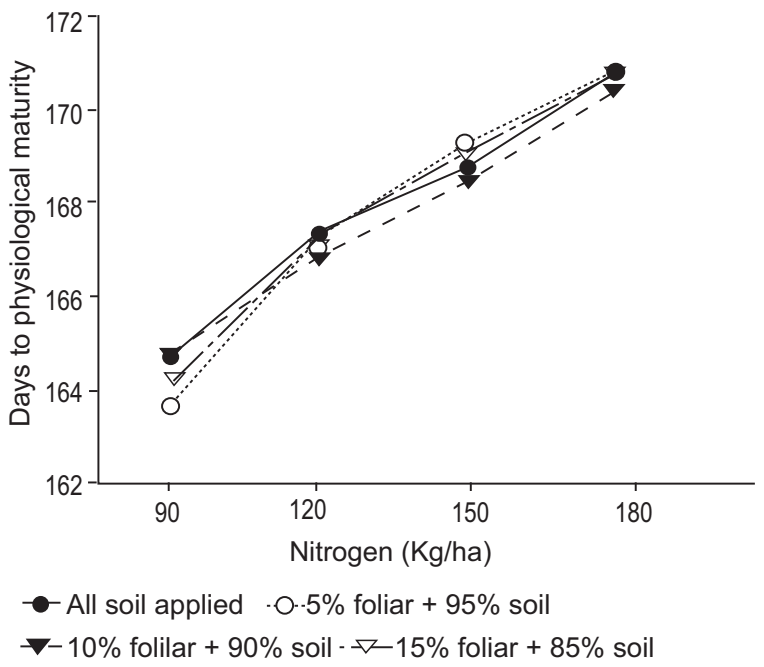

Fig. 4. Interaction $\mathrm{N} \times \mathrm{M}$ for physiological maturity.

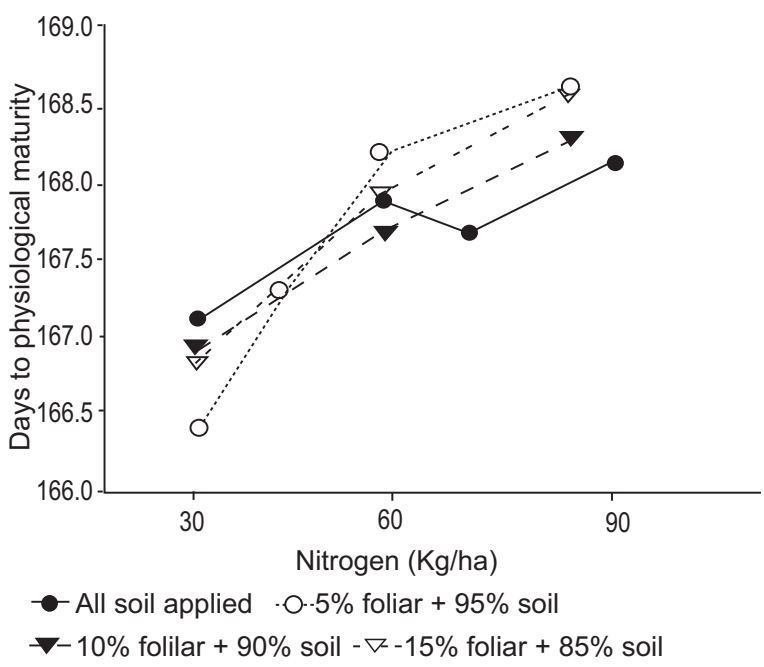

Fig. 5. $\mathrm{K} \times \mathrm{M}$ interaction for physiological maturity. when complete dose of $180 \mathrm{Kg}$, N/ha was directly applied to soil with no foliar application.

$\mathbf{N}$ and $\mathrm{K}$ interaction for leaf area/tiller of wheat. Leaf area/tiller increased profoundly with increase in $\mathrm{N}$ and K (Fig. 8) simultaneously and attained maximum value when both $\mathrm{N}$ and $\mathrm{K}$ were at their highest rate. Decreasing $\mathrm{N}$ and $\mathrm{K}$ rate decreased leaf area/tiller with minimum value recorded when $\mathrm{N}$ was applied at the rate of $90 \mathrm{Kg} / \mathrm{ha}$ with $\mathrm{K}$ at the rate of $30 \mathrm{Kg} / \mathrm{ha}$.

Leaf area/tiller of wheat in response to methods and $\mathbf{N}$ interaction. Methods and $\mathrm{N}$ interaction (Fig. 9) indicated that as the percentage of foliar application of $\mathrm{N}$ increased leaf area/tiller increased also across all

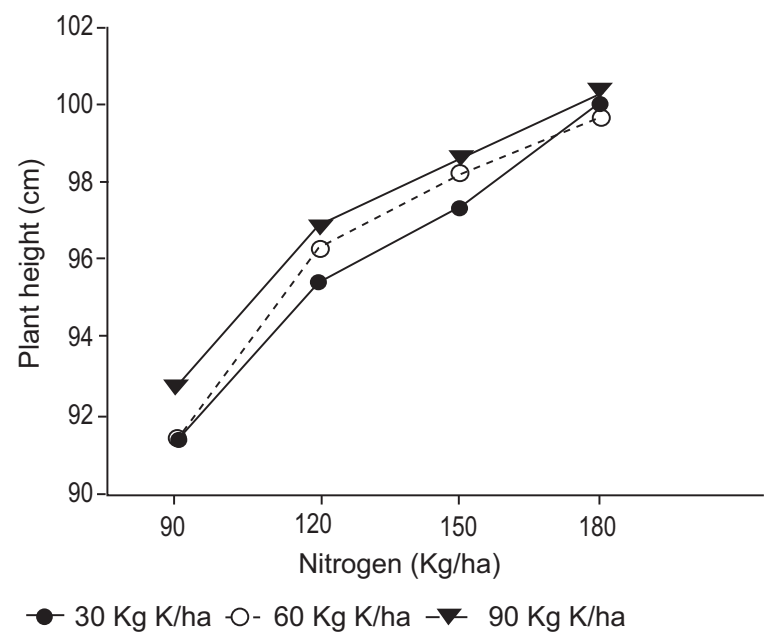

Fig. 6. $\mathrm{N} \times \mathrm{K}$ interaction for plant height.

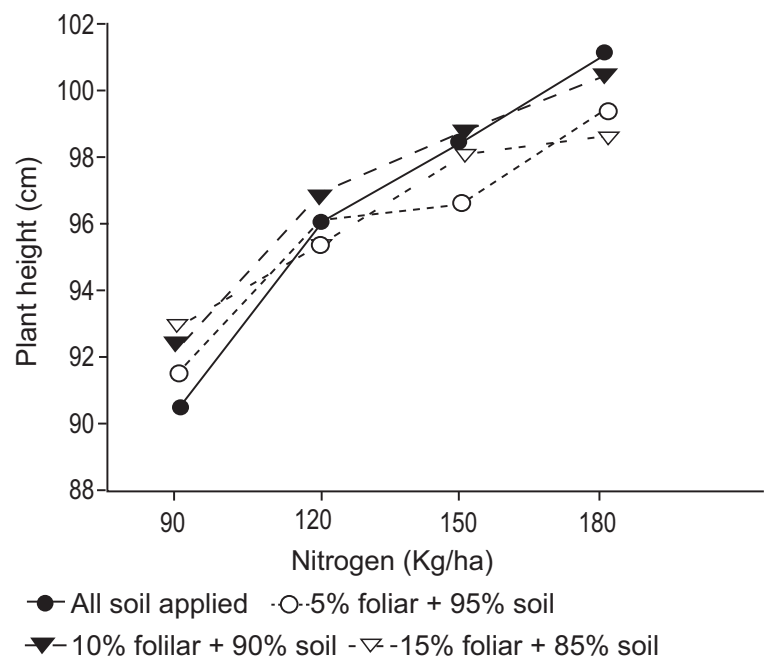

Fig. 7. Interaction of $\mathrm{N} \times \mathrm{M}$ for plant height. 
levels of N. Maximum leaf area/tiller was recorded when $180 \mathrm{Kg} / \mathrm{ha} \mathrm{N}$ was applied in such a way that $15 \%$ was supplied through foliar and $85 \%$ through soil application while minimum leaf area/tiller was recorded when $90 \mathrm{Kg} / \mathrm{ha} \mathrm{N}$ was completely applied to soil.

Impact of $\mathbf{N}$ and $\mathrm{K}$ interaction on flag leaf area/tiller of wheat. Flag leaf area/tiller profoundly increased when both $\mathrm{N}$ and $\mathrm{K}$ (Fig. 10) was increased simultaneously and attained maximum value when both $\mathrm{N}$ and $\mathrm{K}$ were at their highest rate i.e. 180 and $90 \mathrm{Kg} / \mathrm{ha}$. Minimum flag leaf area/tiller was recorded when both $\mathrm{N}$ and $\mathrm{K}$ was at their lowest rate i.e. 90 and $30 \mathrm{Kg} / \mathrm{ha}$, respectively.

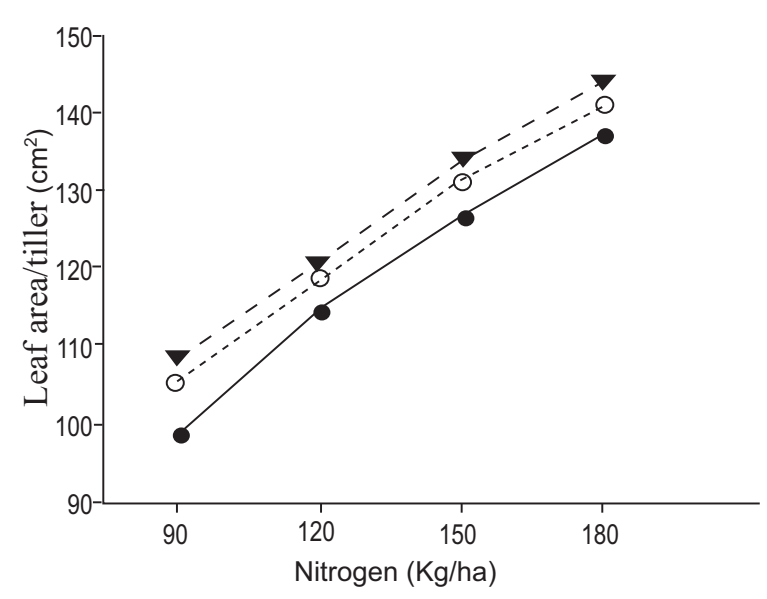

$30 \mathrm{Kg} \mathrm{K} / \mathrm{ha}-0-60 \mathrm{Kg} \mathrm{K} / \mathrm{ha}-\boldsymbol{\nabla} 90 \mathrm{Kg} \mathrm{K} / \mathrm{ha}$

Fig. 8. $\mathrm{N} \times \mathrm{K}$ interaction for leaf area/tiller.

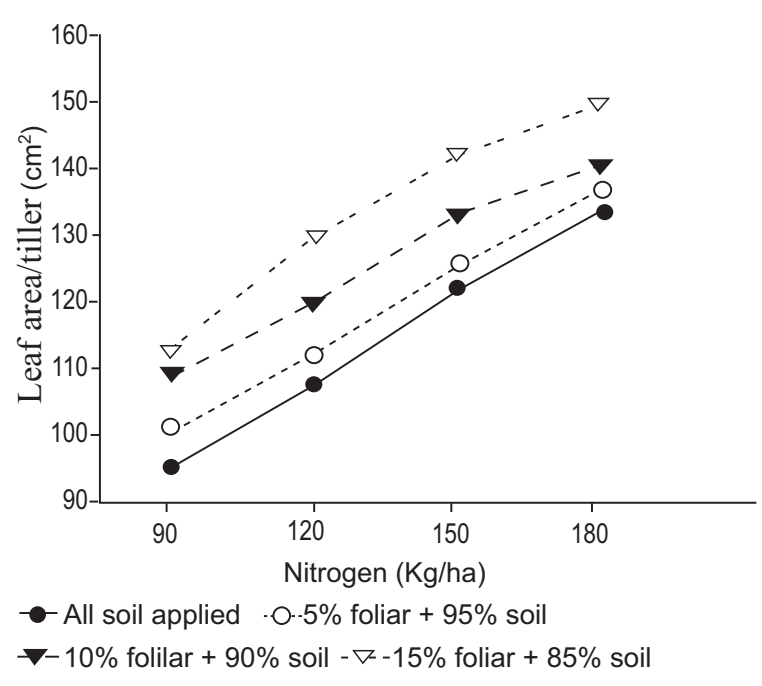

Fig. 9. Interaction of $\mathrm{N} \times \mathrm{M}$ for leaf area/tiller.
Impact of methods and $\mathrm{N}$ interaction on flag leaf area/tiller of wheat. Methods into $\mathrm{N}$ interaction (Fig. 11) showed that when $\mathrm{N}$ was applied directly into the soil resulted in minimum flag leaf area/tiller and increasing ratio of foliar application significantly increased flag leaf area/tiller across all level of N. Maximum flag leaf area/tiller was recorded when 180 $\mathrm{Kg}, \mathrm{N} / \mathrm{ha}$ was applied in such a way that $15 \% \mathrm{~N}$ was supplied through foliar and rest through soil application which was statistically similar to ratio of 10:90 (foliar: soil).

Methods and $\mathrm{K}$ interaction for flag leaf area/tiller of wheat. This interaction clearly indicated that increase

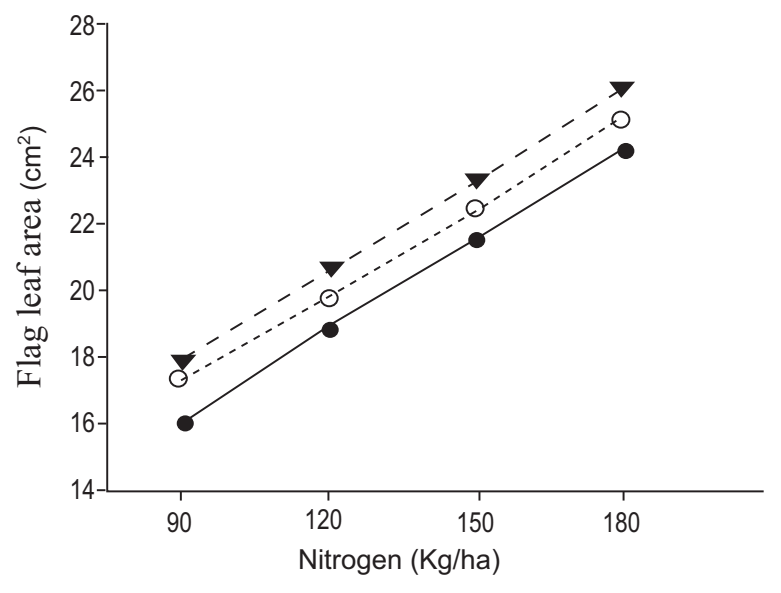
$30 \mathrm{Kg} \mathrm{K} / \mathrm{ha}-0-60 \mathrm{Kg} \mathrm{K} / \mathrm{ha}-\boldsymbol{\nabla} 90 \mathrm{Kg} \mathrm{K} / \mathrm{ha}$

Fig. 10. $\mathrm{N} \times \mathrm{K}$ interaction for flag leaf area $\left(\mathrm{cm}^{2}\right)$.

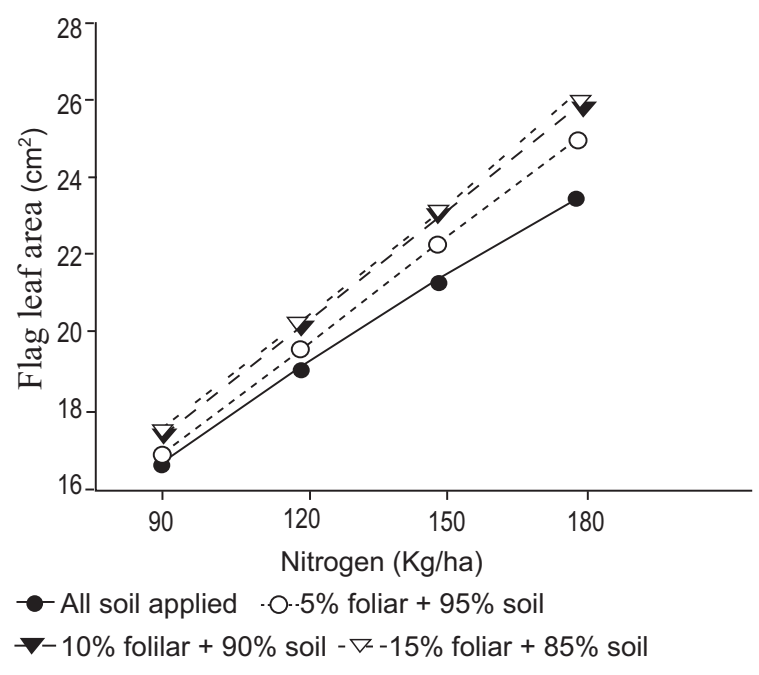

Fig. 11. Interaction of $\mathrm{N} \times \mathrm{M}$ for flag leaf area $\left(\mathrm{cm}^{2}\right)$. 
in ratio of foliar to soil application of $\mathrm{K}$ profoundly increased flag leaf area/tiller with increase in $\mathrm{K}$ rate simultaneously (Fig. 12). Maximum flag leaf area/tiller was recorded when $\mathrm{K}$ was applied at the rate of 90 $\mathrm{Kg} / \mathrm{ha}$ in the ratio of 15:85 as foliar: soil application respectively.

Leaf area index of wheat in response to methods and $\mathbf{N}$ interaction. Methods into $\mathrm{N}$ interaction (Fig. 13) indicated that leaf area index increased linearly across all levels of application methods and attained maximum value when $15 \%$ of $\mathrm{N}$ was applied through foliar and $85 \%$ directly to soil to provide a total of $180 \mathrm{Kg}, \mathrm{N} / \mathrm{ha}$.

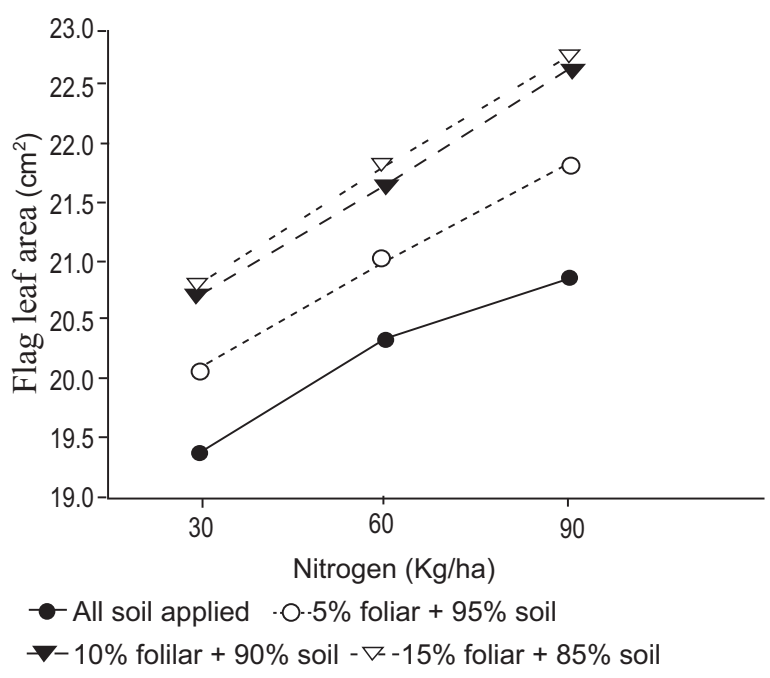

Fig. 12. Interaction of $M \times K$ for flag leaf area $\left(\mathrm{cm}^{2}\right)$.

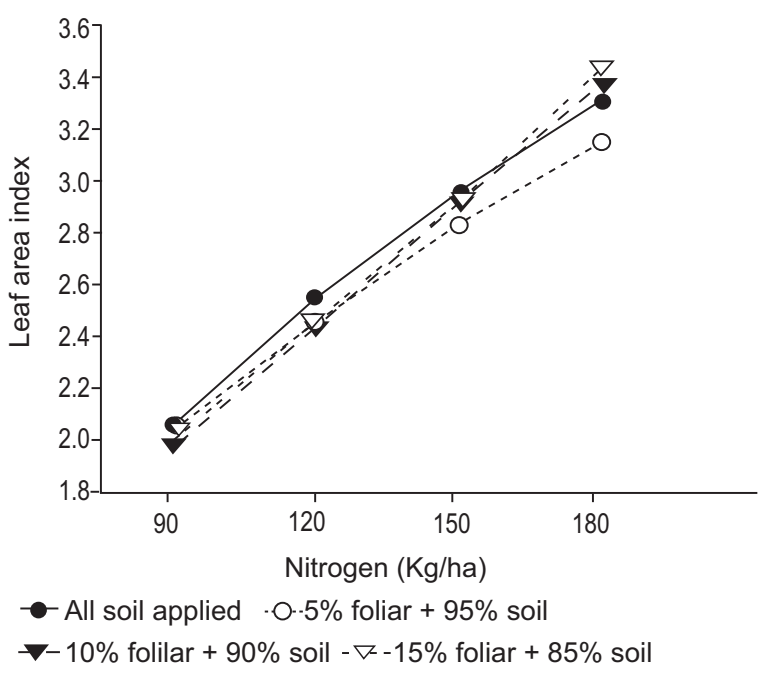

Fig. 13. N x M interaction for leaf area index.
Grain yield of wheat in response to methods and $\mathbf{N}$ interaction. Interaction (Fig. 14) showed that increase in $\mathrm{N}$ level increased grain yield weather applied directly to soil or in combination with foliar except for treatment of $5 \%$ foliar $+95 \%$ soil which decreased yield when $\mathrm{N}$ was increased from $150 \mathrm{Kg} / \mathrm{ha}$ to $180 \mathrm{Kg} / \mathrm{ha}$. Maximum grain yield was recorded when $\mathrm{N}$ was applied at the rate of $180 \mathrm{Kg} / \mathrm{ha}$ in such a combination that $15 \% \mathrm{~N}$ was applied through foliar and remaining through soil application. Application of $90 \mathrm{Kg}, \mathrm{N} /$ ha directly to soil resulted in lower grain yield.

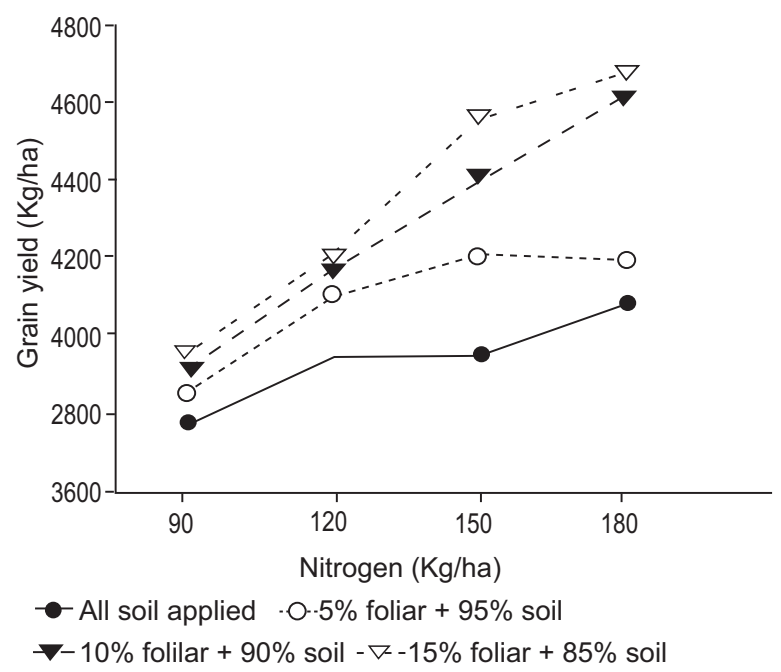

Fig. 14. Interaction of $\mathrm{M} \times \mathrm{N}$ for grain yield (Kg/ha).

Interaction between $\mathrm{N}$ and $\mathrm{K}$ for $\mathrm{N}$ uptake by grains of wheat. Simultaneous increase of $\mathrm{N}$ and $\mathrm{K}$ substantially increased $\mathrm{N}$ uptake by grains (Fig. 15). Maximum $\mathrm{N}$ uptake by grains was recorded when both $\mathrm{N}$ and $\mathrm{K}$ was applied at their highest rate i.e. 180 and $90 \mathrm{Kg} / \mathrm{ha}$. Minimum $\mathrm{N}$ uptake by grains was recorded when $\mathrm{N}$ was applied at the rate of 90 with $\mathrm{K}$ at the rate of 30 $\mathrm{Kg} / \mathrm{ha}$.

Methods and $\mathbf{N}$ interaction for $\mathbf{N}$ uptake by grains of wheat. $\mathrm{N}$ uptake by grains increased with increase in ratio of foliar to soil $\mathrm{N}$ application with maximum $\mathrm{N}$ uptake by grains (Fig. 16) recorded for $180 \mathrm{Kg}$, N/ha applied in such a way that $15 \%$ and $85 \% \mathrm{~N}$ was supplied through foliar and soil application respectively. Minimum $\mathrm{N}$ uptake by grains was recorded when $90 \mathrm{Kg} / \mathrm{ha} \mathrm{N}$ was applied directly to the soil.

Impact of methods and $\mathrm{K}$ interaction for $\mathrm{N}$ uptake by grains of wheat. Methods and $\mathrm{K}$ interactions 
(Fig. 17) revealed that minimum $\mathrm{N}$ uptake by grains was recorded when complete dose of $30 \mathrm{Kg}$ /ha $\mathrm{K}$ was applied directly to soil which increased with increase in $\mathrm{K}$ rate. Increase in ratio of foliar to soil application of $\mathrm{N}$, uptake of $\mathrm{N}$ by grains increased across all levels of $\mathrm{N}$ and attained maximum value when $180 \mathrm{Kg} / \mathrm{ha} \mathrm{N}$ was applied in the ratio of 15: 85 (foliar: soil).

$\mathrm{N}$ uptake by straw of wheat in response to $\mathrm{N}$ and $\mathrm{K}$ interaction. $\mathrm{N}$ and $\mathrm{K}$ interaction (Fig. 18) significantly increased $\mathrm{N}$ uptake by straw of wheat crop. A continuous increase was observed in $\mathrm{N}$ uptake by straw when both $\mathrm{N}$ and $\mathrm{K}$ were increased simultaneously. Maximum $\mathrm{N}$

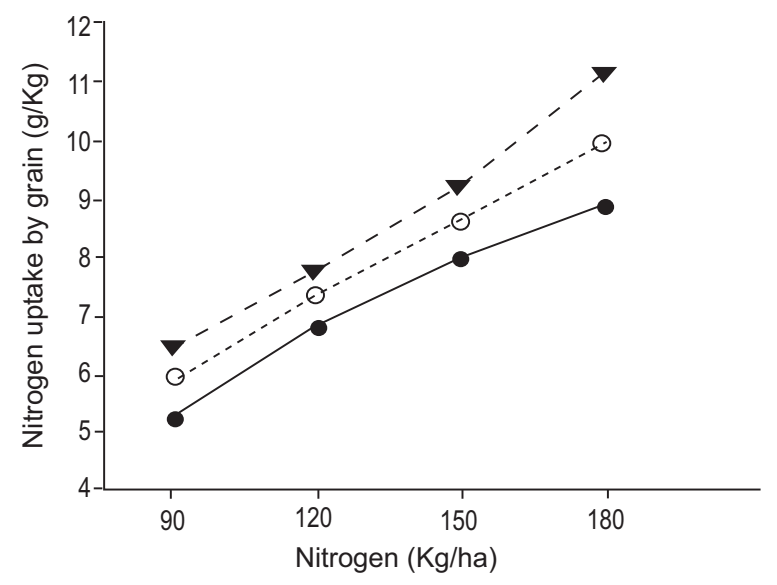

$30 \mathrm{Kg} \mathrm{K} / \mathrm{ha}-0-60 \mathrm{Kg} \mathrm{K} / \mathrm{ha}-\boldsymbol{\nabla} 90 \mathrm{Kg} \mathrm{K} / \mathrm{ha}$

Fig. 15. Interaction of $\mathrm{N} \times \mathrm{K}$ for $\mathrm{N}$ uptake by grain.

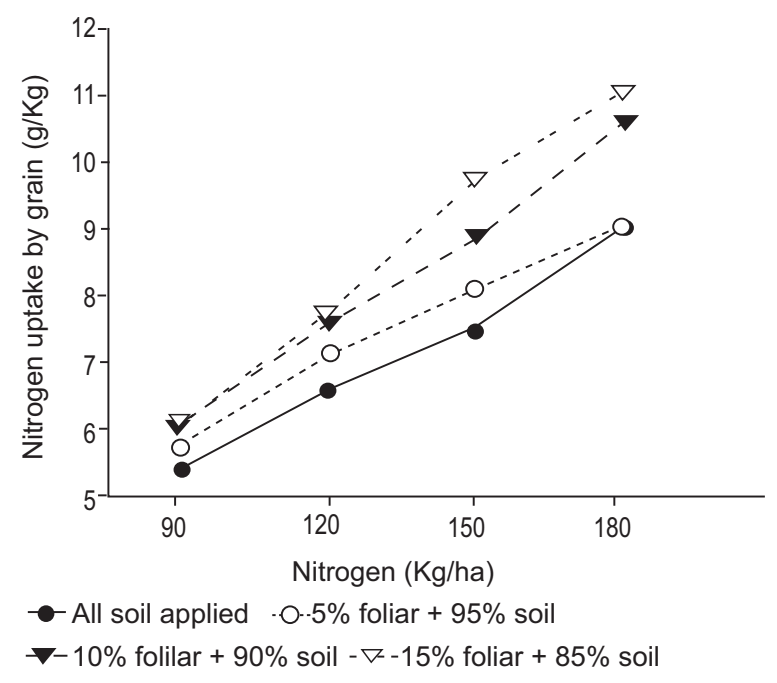

Fig. 16. Interaction of $\mathrm{N} \times \mathrm{M}$ for $\mathrm{N}$ uptake by grain. uptake by straw was recorded when both nutrients ( $\mathrm{N}$ and $\mathrm{k}$ ) was applied at their highest rate.

Methods and $\mathbf{N}$ interaction for $\mathbf{N}$ uptake by straw of wheat. This interaction (Fig. 19) revealed that minimum $\mathrm{N}$ uptake by straw was observed when $90 \mathrm{Kg}$ /ha $\mathrm{N}$ was supplied in such a way that $10 \% \mathrm{~N}$ was applied through foliar and $90 \%$ through soil application. Maximum $\mathrm{N}$ uptake by straw was recorded when $180 \mathrm{Kg}$, N/ha was applied in such a way that $15 \%$ and $85 \% \mathrm{~N}$ was supplied through foliar and soil application respectively.

Nitrogen and potassium. Crop phenology is a vital phenomenon and can affect wheat productivity. Phenological parameters like days to anthesis and

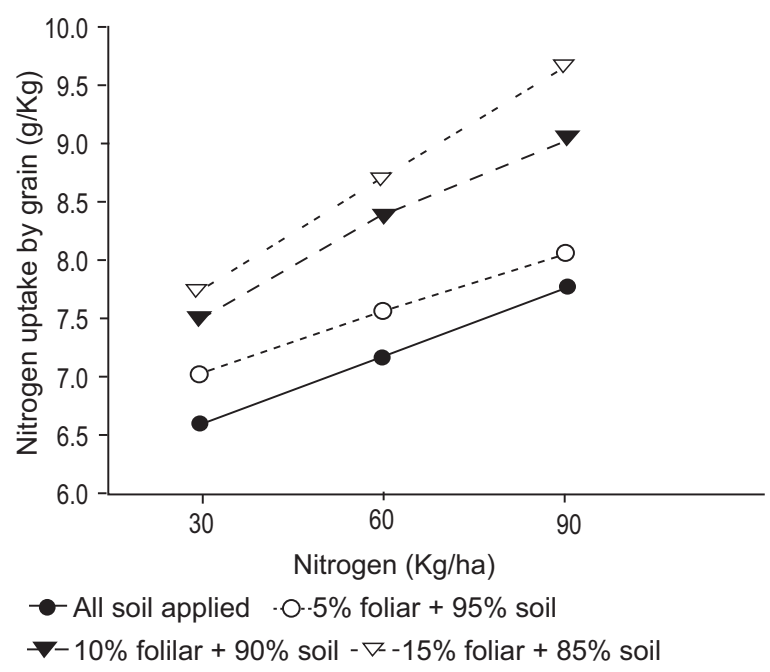

Fig. 17. Interaction of $K \times M$ for $N$ uptake by grain.

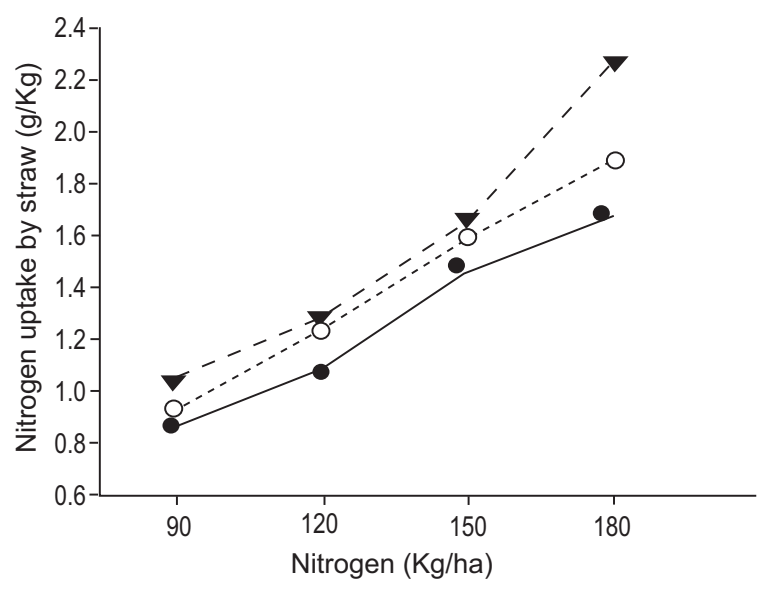

$30 \mathrm{Kg} \mathrm{K} / \mathrm{ha}-0-60 \mathrm{Kg} \mathrm{K} / \mathrm{ha} \rightarrow 90 \mathrm{Kg} \mathrm{K} / \mathrm{ha}$

Fig. 18. $\mathrm{N} \times \mathrm{K}$ interaction for $\mathrm{N}$ uptake by straw. 


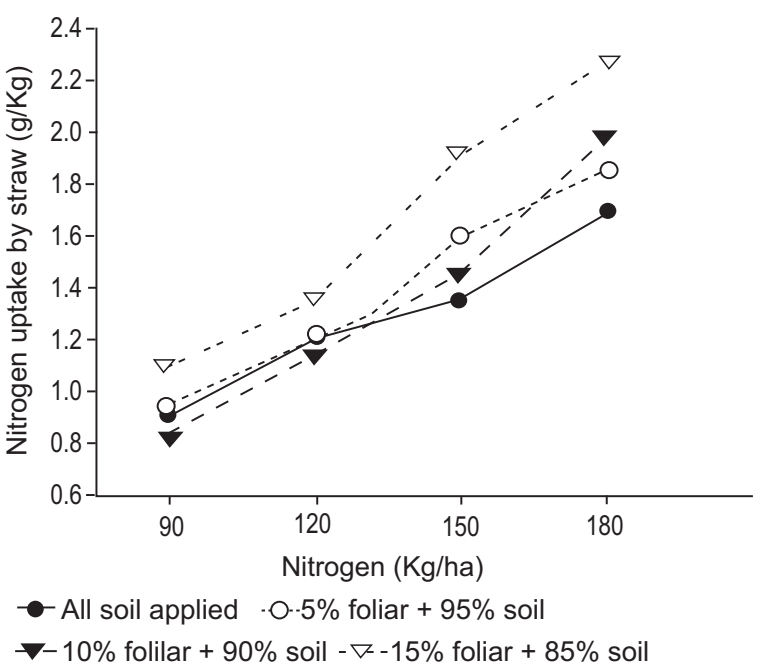

Fig. 19. Interaction of $\mathrm{N} \times \mathrm{M}$ for $\mathrm{N}$ uptake by straw.

maturity play a significant role in the final crop yield. Days to anthesis and maturity increased with increasing rate of $\mathrm{N}$ and $\mathrm{K}$. More days taken to anthesis and maturity might be due to continuous cell division and multiplication with sufficient amount of $\mathrm{N}$ and $\mathrm{K}$ which prolonged vegetative stage as reported by Hameed et al. (2003). Delayed anthesis and maturity could be attributed to increase in leaf area duration, vegetative growth and enhanced light use efficiency with the use of $\mathrm{N}$ fertilizer (Delden, 2001). Increasing $\mathrm{N}$ rate increased water use efficiency and duration of growth stages (Deng et al., 2004). Our findings are in line with Shahzad and Akmal (2017) who reported delay in maturity with increasing $\mathrm{N}$ rate due to extended grain filling duration. Increase in $\mathrm{K}$ level significantly delayed maturity probably because of enormous vegetative growth (Seilsepour, 2007).

Plant height increased linearly with each successive increase in rate of $\mathrm{N}$ and $\mathrm{K}$ which might be attributed to better and vigorous vegetative growth due to application of $\mathrm{N}$ and $\mathrm{K}$ (Ayub et al., 2002). Increase in plant height due to $\mathrm{K}$ was also observed by Kubar et al. (2019). A linear increase was observed in plant height with simultaneous increase in the levels of $\mathrm{N}$ and $\mathrm{K}$. Adnan et al. (2016) reported that plant height increased when $\mathrm{N}$ was applied in combination with $\mathrm{K}$ probably because carbohydrates were more rapidly converted into proteins by application of $\mathrm{N}$ which ultimately changed into protoplasm, thus increased cell size and finally plant height. Leaf area/tiller and flag leaf area increased significantly with the application of $\mathrm{N}$ and K. Fertilizer application to wheat particularly $\mathrm{N}$ and $\mathrm{K}$ during early stages of plant growth greatly increased leaf area by keeping leaves green, sustained leaf photosynthesis and prolonged leaf area duration which ultimately resulted in maximum leaf area compared with control as reported by Zhang et al. (1998). Application of $\mathrm{N}$ increased assimilates content in leaf which might increase leaf area. Application of $\mathrm{N}$ stimulates leaf growth and thus increases leaf area (Khan et al., 2008). Our outcomes are supported by the results of Delden (2001) who reported that leaf area decreased with decrease in $\mathrm{N}$ fertilization.

Leaf area index is one of the major physiological determinant of the crop final yield. Increasing $\mathrm{N}$ and $\mathrm{K}$ rate increased LAI which might be attributed to enhanced leaf area on account of more accumulation of assimilates. Also, increased in tillers and size of leaves due to increased rate of $\mathrm{N}$ and $\mathrm{K}$ might enhanced LAI. Heinemann et al. (2006) recorded highest LAI at increasing rate of mineral N. Kibe et al. (2006) indicated that leaf area and LAI was higher in $\mathrm{N}$ fertilized plots than control. Leaf area duration increased significantly with the application of $\mathrm{N}$ and $\mathrm{K}$ nutrients. Foulkes et al. (2007) reported that prolonged green flag leaf area was related with the ability of the crop to produce more yield. Leaf area duration increased with increased $\mathrm{N}$ level (Basit, 2003). Grain yield increased significantly with application of $\mathrm{N}$ and $\mathrm{K}$ nutrients. Improvement in grain yield of wheat might be due to the collective role of $\mathrm{N}$ and $\mathrm{K}$ as reported by Deng et al. (2004). Grain yield increased considerably with increase in application of N levels. It was indicated by Foyer et al. (2002) that $\mathrm{N}$ played a key role in photosynthesis of plants and thus increased grain yield of the crop. Maximum grain yield might be attributed to the improvement in number of tillers, spike length, grain/spike and 1000 grains weight. Similar results were obtained by Singh et al. (2002) who reported that increasing $\mathrm{N}$ rates increased grain yield. Maqsood et al. (2002) found that application of $150 \mathrm{Kg}, \mathrm{N} / \mathrm{ha}$ gave the highest grain yield. Grain yield showed profound increase with increase in the application of $\mathrm{K}$ levels. K increased root growth, reduced water loss and wilting, enhanced drought resistance (Tiwari, 2002) thus might resulted in more grain yield. Potassium might have increased the rate of $\mathrm{CO}_{2}$ assimilation, stabilized osmosis regulation, improved stomata closure and enzyme activity as a result of which more carbohydrates might have produced which 
ultimately increased grain yield as recorded by Tabatabaii et al. (2011).

Nitrogen uptake by wheat grains and straw in response to $\mathbf{N}$ and $\mathbf{K}$ fertilization. Nitrogen uptake by wheat grains and straw increased by increasing $\mathrm{N}$ and $\mathrm{K}$ fertilization, because they are the most important nutrients for plants, where many physiological processes rely on them, especially those responsible for absorbing elements by enhancing roots and thus increasing the concentration of nutrients in plant such as $\mathrm{N}$. Baque et al. (2006) reported that uptake of $\mathrm{N}$ was enhanced with increasing K levels. Antoun et al. (2010) obtained similar results. Mosaad and Fouda (2016) reported the same findings that increasing $\mathrm{K}$ rate significantly increased $\mathrm{N}$ uptake by grains and straw. $\mathrm{N}$ uptake by straw and grain substantially increased by increasing $\mathrm{N}$ rate (Antoun et al., 2010). Seadh et al. (2009) reported that fertilization with a higher $\mathrm{N}$ dose has the most favorable effect on the contents of $\mathrm{N}$ in wheat grain. $\mathrm{N}$ uptake by grains increased significantly with the application of $\mathrm{N}$ and K (Hassan et al., 1996).

Application methods of $\mathbf{N}$ and $\mathbf{K}$. Foliar application of urea has been proved to be an effective technique of $\mathrm{N}$ fertilization. The adoption of foliar urea may help reduce the losses due to denitrification, leaching and immobilization, often associated with $\mathrm{N}$ fertilization to the soil system (Gooding, 2005).

In our experiment, the application of urea and murate of potash through soil + foliar spray at 180 and $90 \mathrm{Kg}$, $\mathrm{N} / \mathrm{ha}$ in the ratio of 10:90 (foliar: soil) increased plant height while ratio of 15:85 substantially increased leaf area/tiller, flag leaf area/tiller, grain yield, $\mathrm{N}$ uptake by grains and straw. This suggested the quick absorption of $\mathrm{N}$ and $\mathrm{K}$ due to foliar spray. The above findings are in line with the previous studies (Mahajan et al., 2004; Abdi et al., 2002; Masauskas and Masauskiene, 2002; Siuliouskas et al., 2001; Jakhro et al., 2000; Emam and Borijan, 2000). These studies reported that foliar spray of $\mathrm{N}$ along with soil application increased growth, yield components and yield as compared to single mode of soil application. The effectiveness of foliar applied urea is reported up to $90-160 \%$ to that of soil application (Czuba, 1994). This might suggest the better utilization and quicker absorption of $\mathrm{N}$ by plants through foliar spray of urea. Khokhar (1985) reported that applying urea through soil application resulted about $50 \% \mathrm{~N}$ loss due to volatilization and leaching. Application of $\mathrm{N}$ and $\mathrm{K}$ in combination of foliar and soil enhanced plant height than complete supply of these nutrients to soil. This might be due to quick absorption of these nutrients through leaf when applied as foliar which cause vigorous vegetative growth and resulted in taller plants. Foliar application of $\mathrm{N}$ and $\mathrm{K}$ significantly increased plant height as reported by Lloveras et al. (2001). Grain yield increased linearly when $15 \%$ of the nutrients were applied to the crop as foliar spray. Foliar spray at flowering and at peak vegetative stage increased grain growth and as a result higher grain yield was produced as reported by Eman and Mogied (1989). Zafar and Mohammad (2007) investigated that foliar spray of N increased grain yield of wheat. Narang et al. (1997) reported that foliar application of $\mathrm{K}$ increased grain yield. Our results are in accordance with the findings of (Abdi et al., 2002; Siuliouskas et al., 2001) and Gooding (2005). These researchers reported that foliar spray of urea/ $\mathrm{N}$ along with soil application increased $\mathrm{N}$ content in straw and grain. It was observed that integrated application of $\mathrm{N}$ through soil and foliage facilitated the higher $\mathrm{N}$ uptake in plants as also investigated by Vagen (2003).

\section{Conclusion}

It is revealed from the experimental results that application of nitrogen $(\mathrm{N})$ and potassium $(\mathrm{K})$ in different ratios as foliar and soil markedly enhanced growth, yield and $\mathrm{N}$ uptake of wheat crop. Application of $\mathrm{N}$ and $\mathrm{K}$ at the rate of 180 and $90 \mathrm{Kg} /$ ha respectively improved growth, yield and $\mathrm{N}$ uptake when applied in such a way that $15 \%$ nutrients $(\mathrm{N}$ and $\mathrm{K})$ were applied as foliar and remaining $85 \%$ through soil application. Further research on different rates of $\mathrm{N}$ and $\mathrm{K}$ with various ratios as foliar and soil is also recommended to improve wheat and others major crops yield.

Conflict of Interest. The authors declare no conflict of interest.

\section{References}

Abdi, M., Mohamadi, G.N., Golchin, A. 2002. The influence of foliar nutrition of urea and potassium chloride on grain yield, grain protein content, yield components and leaf relative water content of Sardari wheat under rainfed condition. The Journal of Agricultural Science, 8: 29-38.

Adnan, M., Shah, Z., Ullah, H., Khan, B., Arshad, M., Mian, I.A., Khan, G.A., Alam, M., Basir, A., Rahman, I., Ali, M., Khan, W.U. 2016. Yield 
response of wheat to nitrogen and potassium fertilization. Pure and Applied Biology, 5: 868875.

Amanullah, Khan, A.Z., Jan, A., Shah, Z., Ahmad, B., Khalil, S.K., Ali, A., Hidayatullah, Ahmad, F., Nawaz, A. 2013. Foliar application of nitrogen at different growth stages influences the phenology, growth and yield of maize (Zea mays L.). Soil and Environment, 32: 135-140.

Antoun, L.W., Zakaria, S.M., Rafla, H.H. 2010. Influence of composit, $\mathrm{N}$ mineral and humic acid on yield and chemical composition of wheat plants. Journal of Soil Sciences and Agricultural Engineering, 1: 1131- 1143.

Ayub, M., Nadeem, M.A., Sharar, M.S., Mahmod, M. 2002. Response of maize (Zea mays L.) to different levels of nitrogen and potassium fertilizer. Asian Journal of Plant Sciences, 4: 352-354.

Bakht, J., Shafi, M., Zubair, M., Khan, M.A., Shah, Z. 2010. Effect of foliar vs soil application of nitrogen on yield and yield components of wheat varieties. Pakistan Journal of Botany, 42: 2737-2745.

Baque, M.A., Karim, M.A., Hamid, A., Tetsushi, H. 2006. Effect of fertilizer potassium on growth, yield nutrient uptake of wheat (Triticum aestivum) under water stress conditions. South Pacific Studies, 27: 25-35.

Basit, A. 2003. Growth, development and yield of wheat (Triticum aestivum L.) under different levels of irrigation and nitrogen. M.Sc (Hons) Thesis, Department of Agronomy, University of Agriculture, Faisalabad.

Bremner, J.M., Mulvaney, C.S. 1982. Nitrogen. In: Methods of Soil Analysis: Page, A.L., Miller, R.H. and Keeney, D.R. (eds.). Part II. Chemical and Microbiological Properties, $2^{\text {nd }}$ eds. American Society of Agronomy, Madison. WI, USA.

Bukhsh, M.A.A.H.A., Ahmad, R., Iqbal, J., Maqbool, M.M., Ali, A., Ishaque, M., Hussain, S. 2012. Nutritional and physiological significance of potassium application in maize hybrid crop production. Pakistan Journal of Nutrition, 11: 187-202.

Czuba, R. 1994. The results of foliar nutrition of field crops II. Response of plants to foliar nitrogen application, Rocznik-Gleboznawcze, 45: 69-78.

Delden, A.V. 2001. Yield and growth components of potato and wheat under organic nitrogen management. Agronomy Journal, 93: 1370-1385.

Deng, X.P., Shan, L., Zhang, H., Turner, N.C. 2004. New directions for a diverse planet. In: Proceeding of the 4th International Crop Sci. Congress, Sep. 26-Oct.1st, 2004, Brisbane, Australia.

EL-Shal, R. 2016. Effect of urea and potassium sulfate fertilizers combined with Boron on soil fertility and sugar beet productivity in salt affected soil. Egyptian Journal of Soil Science, 56: 665-681.

Emam, Y., Borijan, A.R. 2000. Yield and yield components of two wheat (Triticum aestivum L.) cultivars in response to rate and time of foliar urea application. Journal of Agricultural Science and Technology, 2: 37-52.

Eman, Y., Mogied, G.P. 1998. The effect of foliar spray of urea at grain filling period on grain yield and grain protein content of winter wheat. Crop Research Hisar, 15: 135-139.

Feng, Z., Liu, A., Yi, J., Li, R., Wang, X., Zou, Q. 2014. Effects of amount of applying potassium fertilizer on yield, fiber quality and potassium fertilizer application efficiency of three hybrid cotton cultivars. Journal of Hunan Agricultural University, 39: 343-347.

Foulkes, M.J., Sylvester, R.B., Weightman, R., Snape, J.W. 2007. Identifying physiological traits associated with improved drought resistance in winter wheat. Field Crops Research, 103: 11-24.

Foyer, C.H., Vanacker, H., Gomez, L.D., Harbinson, J. 2002. Regulation of photosynthesis and antioxidant metabolism in maize leaves at optimal and chilling temperatures: a review. Plant Physiology and Biochemistry, 40: 659-668.

Gab-Alla, F.I., Gomaa, M.A., El-Araby, F.I. 2003. Effect of nitrogen fertilizer and some micronutrients as foliar application on wheat. Annals of Agricultural Sciences, 31: 273-289.

Gooding, M.J. 2005. Foliar urea fertilisation and the management of yield and quality in wheat. International Fertiliser Society Proceedings, 573.

Hameed, E., Shah, W.A., Shad, A.A., Bakht, J., Muhammad, T. 2003. Effect of different planting dates, seed rate and nitrogen levels on wheat. Asian Journal of Plant Sciences, 2: 467-474.

Hassan, G., Gill, K.H., Chaudhry, E.H., Sial, R.A., Ehsan. B.A. 1996. Assessment of individual and combined impact of NPK on wheat and rice. Pakistan Journal of Agricultural Sciences, 12: 8185.

Heinemann, A.B., Stone, L.F., Agostinho, D.D., Trindade, M.G., Soares, B.B., Moreira, J.A.A., Canovas, A.D. 2006. Solar radiation use efficiency on the wheat grain yield as a function of nitrogen 
fertilizer. Revista Brasileira de Engenharia Agricola e Ambiental, 10: 352-356.

Hong-Bo, S., Xiao-Yan, C., Li-Ye, Z., Xi-Ning, W., Gangh, Y., Yong-Bing, Z., Chang-Xing, Z., ZanMin. 2006. Investigation on the relationship of proline with wheat antidrought under soil water deficits. Colloids and Surfaces B: Biointerfaces, 53: 113-119.

Jakhro, A.A., Jamro, G.H., Jamali, N.M., Jamali, L.A., Sheikh, S.A. 2000. Effect of foliar fertilization of urea on the quantitative and qualitative traits of wheat (cv. Sarsabz). Pakistan Journal of Agriculture, Agricultural Engineering and Veterinary Sciences, 16: 5-9.

Johnson, A.J., Prince, J. 2002. Effect of adding sulphur to urea sprays at milky ripe on protein content of winter wheat. Annals of Applied Biology, 15: 371372.

Khan, A. A., Inamullah, Jan, M.T., Shah, S., Akbar, H. 2015. Level and application method of nitrogen and potassium affect grain yield and quality of wheat. Basic Research Journal of Agricultural Sciences Review, 4: 56-63.

Khan, A., Jan, M.T., Arif, M., Marwat, K.B., Jan, A. 2008. Phenology and crop stand of wheat as affect by nitrogen sources subjected to different tillage practices. Pakistan Journal of Botany, 40: 11031112.

Khokhar. 1985. Effect of foliar feeding of urea on the yield and quantity of wheat. M.Sc. Thesis, Deptt. Agric. Chemis. SAU. Tando Jam, Sindh, Pakistan.

Kibe, A.M., Singh, S., Kalra, N. 2006. Water-nitrogen relationships for wheat growth and productivity in late sown conditions. Agricultural Water Management, 84: 221-228.

Kubar, G.M., Talpur, K.H., Muhammad, N.K., Khashkhali, S., Nizamani, M.M., Kubar, M.S., Kubar, K.A., Kubar, A.A. 2019. Pure and Applied Biology, 8: 248-255.

Lloveras, J., Lopez, A., Ferran, J., Espachs, S., Solsona, J. 2001. Breadmaking wheat and soil nitrate as affected by nitrogen fertilization in irrigated mediterranean conditions. Agronomy Journal, 93: 1183-1190.

Mahajan, G., Singh, G., Sekhon, G.S. 2004. Effect of phosphorus and foliar application of urea on the growth and yield of summer urdbean genotypes. Abstracts, $10^{\text {th }}$ International Cong. Soil Sciences, Soil Science Society of Pakistan, Tandojam, March 16-19, 2004.
Maqsood, M., Abid, A.M., Iqbal, A., Hussain, M.I. 2002. Effect of variable rate of nitrogen and phosphorus on growth and yield of maize. Online Journal of Biological Sciences, 1: 19-20.

Masauskas, V., Masauskiene, A. 2002. The effect of the foliar applied rates of urea-ammonium nitrate solution UAN-32 and timing on the yield parameters and grain quality of winter wheat. Zemdirbyste Mokslo Darbai, 77: 70-81.

Mosaad, I., Fouda, K.F. 2016. Effect of potassium and nitrogen fertilization on some macro nutrients utilization efficiency by wheat. Egyptian Journal of Soil Science, 56: 373-384.

Narang, R.S., Mahal, S.S., Seema, B., Gosal, K.S., Bedi, S. 1997. Response of rice and wheat of Kfertilization under maximum yield research strategies. Environmental Ecology, 19: 474-477.

Nisar, A., Rashid, M. 2003. Fertilizers and their use in Pakistan. Extension Bulletin. $3^{\text {rd }}$ edition. NFDC, Islamabad, Pakistan.

Seadh, S.E., EL-Abady, M.I., El-Ghamry, A.M., Farouk, S. 2009. Influence of micronutrients foliar application and nitrogen fertilization on wheat yield and quality of grain and seed. Journal of Biological Sciences, 9: 851-858.

Seilsepour, M. 2007. Study of wheat grain protein increasing through foliar application of nitrogen after anthesis. Biaban Desert Journal, 12: 1-5.

Shahzad, K., Akmal, M. 2017. Yield performance of wheat under split $\mathrm{N}$ application rates and timing. Sarhad Journal of Agriculture, 33: 350-356.

Singh, C.B., Kumar, J., Khan, A.A., Katiyar, R.A., Katiyar, A.K. 2002. Effect of nitrogen and dates of sowing on yield and quality of wheat (Triticum aestivum L.) seeds. Progressive Agriculture, 2: 92-93.

Siuliauskas, A., Vagusevicience, I., Liakas, V. 2001. Additional fertilization of winter wheat through leaves. In: Proceeding of International Conference Sustainable Agriculture in Baltic States, Tartu, Estonia, June 28-30.

Tabatabaii, S., Ebrahimi, M., Yarnia, M.B., Khorshidi, B., Tabrizi, E.F.M. 2011. Effect of potassium fertilizer on corn yield (Jet acv.) under drought stress condition. American Eurasian Journal of Agricultural and Environmental Sciences, 10: 257-263.

Tiwari, K.N. 2002. Phosphorus and potassium fertilization reduce dry weather and late harvest risks. Fertilizer Knowledge, 2: 1-2. 
Vagen, I.M. 2003. Nitrogen uptake in a broccoli crop. I. Nitrogen dynamics on a relative time scale. Acta Horticulturae, 627: 195-202.

Wagan, Z.A., Uriro1, M., Wagan, T.A., Wagan, Z.A., Jamro, S.A., Memon, Q.A., Wagan, S.A. 2017. Effect of foliar applied urea on growth and yield of wheat (Triticum aestivium L.). International Journal of Bioorganic Chemistry, 2: 185-191.

Wallace, L. 2001. Sustaining potassium reserves to enhance crops yields. In: Farming Ahead, 118: 4041.

Wang, M., Zheng, Q., Shen, Q., Guo, S. 2013. The critical role of potassium in plant stress response. International Journal of Molecular Sciences, 14:
7370-7390.

Zadoks, J.C., Chang, T.T., Konzak, C.F. 1974. A decimal code for the growth stages of cereals. Weed Research, 14: 415-421.

Zafar, Muhammad, F. 2007. Effect of soil and foliar application of different concentration of NPK and foliar application of $\left(\mathrm{NH}_{4}\right)_{2} \mathrm{SO}_{4}$ on growth and yield attributes in wheat. Pakistan Journal of Plant Sciences, 13: 119-128.

Zhang, H., Oweis, T.Y., Garabet, S., Pala., M. 1998. Water use efficiency and transpiration efficiency of wheat under rainfed conditions and supplemental irrigation in a mediterranean type environment. Plant and Soil, 20: 295-305. 